\title{
A53T Human $\alpha$-Synuclein Overexpression in Transgenic Mice Induces Pervasive Mitochondria Macroautophagy Defects Preceding Dopamine Neuron Degeneration
}

\author{
Linan Chen (陈), Zhiguo Xie, @Susie Turkson, and Xiaoxi Zhuang \\ Department of Neurobiology, University of Chicago, Chicago, Illinois 60637
}

In vitro evidence suggests that the inefficient removal of damaged mitochondria by macroautophagy contributes to Parkinson's disease (PD). Using a tissue-specific gene amplification strategy, we generated a transgenic mouse line with human $\alpha$-synuclein A53T overexpression specifically in dopamine (DA) neurons. Transgenic mice showed profound early-onset mitochondria abnormalities, characterized by macroautophagy marker-positive cytoplasmic inclusions containing mainly mitochondrial remnants, which preceded the degeneration of DA neurons. Genetic deletion of either parkin or PINK1 in these transgenic mice significantly worsened mitochondrial pathologies, including drastically enlarged inclusions and loss of total mitochondria contents. These data suggest that mitochondria are the main targets of $\alpha$-synuclein and their defective autophagic clearance plays a significant role during pathogenesis. Moreover, endogenous PINK1 or parkin is indispensable for the proper autophagic removal of damaged mitochondria. Our data for the first time establish an essential link between mitochondria macroautophagy impairments and DA neuron degeneration in an in vivo model based on known PD genetics. The model, its well-defined pathologies, and the demonstration of a main pathogenesis pathway in the present study have set the stage and direction of emphasis for future studies.

Key words: alpha-synuclein; mitophagy; parkin; PINK1; positive feedback; transgenic model

\section{Introduction}

Mitochondrial homeostasis and proper mitochondria quality control are crucial for cell survival (Nunnari and Suomalainen, 2012), and mitochondria impairments have been the central theme in Parkinson's disease (PD) research (Schon and Przedborski, 2011). A more specific hypothesis regarding the role of mitochondria impairment in PD has emerged with the discoveries that loss-of-function mutations in parkin or PTEN-induced putative kinase 1 (PINK1) cause autosomal recessive PD, and both genes are central in selectively eliminating damaged mitochondria through a macroautophagic pathway (known as mitophagy) (Narendra et al., 2008; de Vries and Przedborski, 2013).

Although the hypothesis implies that the inefficient removal of damaged mitochondria may contribute to some forms of fa-

Received Jan. 8, 2014; revised 0ct. 10, 2014; accepted 0ct. 16, 2014.

Author contributions: L.C. designed research; L.C., Z.X., and S.T. performed research; L.C. contributed unpublished reagents/analytic tools; L.C. and X.Z. analyzed data; L.C. and X.Z. wrote the paper.

This work was supported in part by International Research Grant PDF-IRG-1208 from the Parkinson's Disease Foundation to L.C., the National Center for Research Resources and the National Center for Advancing Translational Sciences of the National Institutes of Health Grant UL1RR024999 to L.C., the Michael J. Fox Foundation for Parkinson's Research RRIA 2012 and RRIA 2013 to L.C., and American Parkinson Disease Association Research Grants to L.C. We thank Carol Swetlik and Jianwei Jiao for technical assistance; and Kay Macleod, Gopal Thinakaran, Ai Yamamoto, and Hui Zhang for comments on the manuscript.

The authors declare no competing financial interests.

Correspondence should be addressed to either Dr. Linan Chen or Dr. Xiaoxi Zhuang, Department of Neurobiology, University of Chicago, 924 E. 57th Street, Knapp R222, Chicago, IL 60637. E-mail: lichen@bsd.uchicago.edu or xzhuang@bsd.uchicago.edu.

DOI:10.1523/JNEUROSCI.0089-14.2015

Copyright $\odot 2015$ the authors $\quad 0270-6474 / 15 / 350890-16 \$ 15.00 / 0$ milial PD (Luoma et al., 2004; Bender et al., 2006; Baloh et al., 2007), two important links are missing in the current literature.

First, existing lines of evidence for the parkin/PINK1dependent mitophagy are mostly based on in vitro non-neuronal preparations using nonselective respiratory chain decoupling drugs. Those studies do not selectively probe the parkin/PINK1 pathway, and mitophagy mechanisms might be different in neurons (Van Laar et al., 2011; Cai et al., 2012; Grenier et al., 2013; Rakovic et al., 2013). Moreover, parkin/PINK1-independent mitophagy mechanisms further complicate the interpretations (Allen et al., 2013; Fu et al., 2013), consistent with the lack of mitophagy impairments in parkin or PINK1-null mice (Youle and Narendra, 2011). Therefore, the relevance of parkin/PINK1dependent mitophagy to $\mathrm{PD}$ needs to be assessed in in vivo $\mathrm{PD}$ models.

Second, whether and how $\alpha$-synuclein, the central player in both sporadic and familial PD (Lee and Trojanowski, 2006), impairs mitochondria and their macroautophagic removal is less clear, despite some, albeit limited, evidence. $\alpha$-Synuclein may translocate to mitochondria, associate with mitochondrial inner membranes, and inhibit complex 1 function, which is worsened by the PD-linked A53T mutation (Devi et al., 2008; Kamp et al., 2010; Nakamura et al., 2011). In addition, $\alpha$-synuclein drives mitochondrial fission and leads to mitochondria fragmentation, which can be rescued by PINK1, parkin, and DJ-1, in cultured cells and in Caenorhabditis elegans (Kamp et al., 2010; Nakamura et al., 2011). However, there is little evidence on whether mitochondria or their macroautophagy are impaired by $\alpha$-synuclein 
and its mutants in dopamine (DA) neurons in vivo (Chinta et al., 2010; Choubey et al., 2011).

Although various transgenic mice with $\alpha$-synuclein overexpression have been well documented, few recapitulate DA neuron loss and mitochondria dysfunction, and none assesses the hypothesized roles of parkin/PINK1 in mitophagy (Dawson et al., 2010). In the present study, we used a "positive feedback" gene expression amplification system and overexpressed the human $\alpha$-synuclein A53T mutant specifically in DA neurons. We found widespread intracellular mitochondrial inclusions, positive for the macroautophagic markers, in nearly all DA neurons, which were followed by DA neuron loss. Remarkably, genetic deletion of either parkin or PINK1 in these mice significantly increased the size of these inclusions and reduced mitochondria mass. Our studies provide the first in vivo evidence that mitochondria damage and their macroautophagic clearance impairment in DA neurons are major pathologies in a PD mouse model.

\section{Materials and Methods}

\section{Transgenic mice}

We used a tetracycline inducible system-based "PF" strategy with amplified expression limited to DA neurons. Similar "PF" gene amplification designs have been reported previously (Shockett et al., 1995; Chen et al., 1998; Götz et al., 2001; Vanrell et al., 2011). However, those systems lack cell type specificity. We used a gene targeting strategy instead in the present study. As shown in Figure $1 A$, the Tet operator (tetO)- tetracycline responsive transactivator (tTA) "PF" cassette was inserted between the DA transporter (DAT) gene promoter and the coding sequence via gene targeting. With this "PF" design, the tetO promoter directs the expression of tTA, which in turn activates the tetO promoter. However, the "PF" cassette by itself has no transcription activity unless it is initiated by tTA expression from another promoter. Therefore, an additional tTA was inserted right downstream of the DAT promoter and upstream of the "PF" cassette. The gene targeting construct also contains a transcriptional "stop" and a floxed PGK-neo cassette for selection during embryonic stem (ES) cell culture. In this DAT-PF-tTA line, the DAT promoter initiates and directs tTA expression only in DA neurons. tTA expression level is then further amplified by the "PF" cassette.

Primogenix PRX-129/S6 ES cells were used for targeting. Male chimeras were crossed with a germ line deleter, Meox2-cre (The Jackson Laboratory), to remove the PGK-neo cassette. The resulting DAT-PF-tTA line was crossed with the $\mathrm{Tg}($ tetO-SNCA $\times$ A53T)E2Cai/J line obtained from The Jackson Laboratory (Lin et al., 2009) to generate $\mathrm{DA}_{\mathrm{SYN} 53}$ double-transgenic mice. The parkin knock-out mice were originally generated in Dr. Jie Shen's laboratory (Goldberg et al., 2003) and purchased from The Jackson Laboratory. The PINK1 knock-out mice that have exons 4-7 and part of exon 8 deleted were generated in our laboratory and previously published (Xiong et al., 2009).

Most mice were fed with a regular lab chew. For some experiments, mice were fed with $200 \mathrm{mg} / \mathrm{kg}$ doxycycline (DOX) pellets (Custom Animal Diets) for 3-6 months to suppress the transgene expression as indicated in the manuscript.

All animal procedures were approved by the Institutional Animal Care and Use Committee at the University of Chicago.

\section{Stereological counting of DA neuron and measuring striatal} tyrosine hydroxylase (TH) staining intensity

$\mathrm{TH}$ catalyzes the rate-limiting step of DA synthesis and was used as a marker for DA neurons in the substantial nigra pars compacta $(\mathrm{SNc})$. The number of TH-immunoreactive (THir) cells was assessed using an unbiased stereological procedure (Chen et al., 2005). Briefly, mice were anesthetized with isofluorane (99.9\%) and transcardially perfused with $1 \times$ PBS and then $4 \%$ PFA. Tissues were postfixed for $12-16 \mathrm{~h}$ and cryoprotected in $30 \%$ sucrose/PBS. Frozen tissues were sectioned serially ( 40 $\mu \mathrm{m})$ on a cryostat and stored in anti-freeze medium at $-20^{\circ} \mathrm{C}$ until use. Every third section was immunohistochemically processed for TH staining and counterstained with cresyl violet. Free-floating sections were blocked in PBS supplemented with 4\% serum, 0.3\% Triton X-100, and $0.01 \%$ thimerosol, and then incubated with primary antibodies overnight at $4^{\circ} \mathrm{C}$. For TH staining, rabbit anti-mouse TH antibody $(1: 1000$, Pel-Freez), biotinylated donkey anti-rabbit IgG (1:500; Jackson ImmunoResearch Laboratories) and peroxidase conjugated avidin-biotin complex (VECTASTAIN Elite ABC kit, Vector Laboratories) were used. The reaction was visualized by using Sigmafast DAB tablets (Sigma). After sections were mounted on slides, cresyl violet staining (FD NeuroTechnologies) was used as a counterstaining.

The estimation of the total number of THir neurons in the SNc was determined using the computerized optical fractionator probe (Stereo Investigator 7, MicroBrightField), which allowed for the stereological estimation of THir cells in the entire structure independent of size, shape, orientation, tissue shrinkage, or anatomical level. The numbers of THir neurons were counted by experimenters blind to genotypes and treatments of transgenic mice. The $100 \times 100 \mu \mathrm{m}$ grid, $40 \times 40 \mu \mathrm{m}$ counting frame, and $3 \mu \mathrm{m}$ guard zones were used. Sections were counted in rostral-caudal order. The absolute THir neuron number was directly calculated without estimating reference volume. The Gundersun's CE (coefficient of error) was $0.06(\mathrm{~m}=1)$ in this study. Nissl-positive neurons in SNc were counted using the same method.

Stereological cell counting for DA neurons in midbrain ventral tegmental area (VTA) was not performed because abundant neuronal fibers in VTA make it technically difficult to accurately determine the guard zones.

The above sections containing striatum were scanned and striatum were outlined in ImageJ (National Institutes of Health). After background staining was subtracted, the total gray value of TH staining in striatum was measured with ImageJ.

\section{Immunofluorescence staining and antibodies}

Sections were processed as above and then incubated overnight at $4^{\circ} \mathrm{C}$ with one or more of the antibodies where indicated. Leica SP5-IISTED-CW confocal microscope was used. For some images, the deconvolution feature in Leica LAS AF was used to increase resolution. Imaris 7.1 software was used for 3D reconstruction.

The following antibodies were used: rabbit polyclonal tyrosine hydroxylase (1:1000, Pel-Freez Biologicals), mouse monoclonal tyrosine hydroxylase (1:1000, BD Transduction Laboratories), guinea pig polyclonal p62/SQSTM1 (1:1000; American Research Products), rabbit polyclonal LC3 (1:200; Novus Biologicals), rabbit polyclonal $\alpha$-synuclein (1: 1000, Cell Signaling Technology), mouse monoclonal $\alpha$-synuclein (SYN1) (1:2000, BD Transduction Laboratories), rabbit polyclonal human $\alpha$-synuclein (1:1000, Enzo Life Sciences), mouse monoclonal human $\alpha$-synuclein (SYN211) (1:2000, Santa Cruz Biotechnology), mouse monoclonal anti-OxPhos Complex IV Subunit I (1:2000, Invitrogen), rabbit polyclonal Mn-SOD(SOD2) (1:100, Millipore), mouse polyclonal PINK1 (1: 400, Abnova), mouse monoclonal parkin (1:200, Covance), mouse monoclonal GM130 (1:500, BD Transduction Laboratories), mouse monoclonal KDEL (1:2000, Enzo Life Sciences), and rabbit polyclonal ubiquitin (1:100, Thermo Scientific, RB9203).

\section{Measuring mitochondria length and mass}

Three midbrain sections per mouse (three mice in each genotype) were double-fluorescence-stained for COX I and TH. Leica SP5-II-STED-CW confocal microscope was used for capturing single neuron using a $100 \times$ objective lens with $6 \times$ digital zoom. The measurements of mitochondria were performed by experimenters blind to genotypes and treatments of transgenic mice. For mitochondria length, the average length of total mitochondria was automatically determined using Fiji (http://fiji.sc) as described here. Briefly, pictures containing only one neuron were first converted to 8-bit gray scale, then background was removed by choosing the appropriate threshold value, and noise was removed by applying a $3 \times 3$ median filter ("Despeckle"). Images were then inverted and mitochondria were skeletonized to one-pixel-wide lines (skeletons) by a "Skeleton" plugin. Each individual skeleton represented a single mitochondrion, and the length of each skeleton represented the length of its corresponding mitochondrion. As the final step, "Analyze particles" was used to automatically measure the length of all skeletons. Of note, because the skeletons were one-pixel-wide, the area reported in "Analyze 
particles" represented the length of skeletons. The average length of mitochondria in a neuron was calculated by dividing the total length of skeletons by the total number of skeletons. Unpaired two-tailed Student's $t$ test was used to reveal the statistic difference of average mitochondria length between genotypes. The skeletonized mitochondria were represented as overlay layers on actual mitochondrial images (see Fig. 5A). For mitochondria mass, COX I staining intensity (excluding mitochondrial inclusions) was measured using ImageJ (National Institutes of Health).

\section{Conventional and immunogold transmission electron microscopy} For conventional electron microscopy (EM), mice were perfused with $4 \%$ PFA and $2.5 \%$ glutaraldehyde in $0.1 \mathrm{M} \mathrm{Na}$ cacodylate, $\mathrm{pH} 7.4$. All reagents were purchased from Electron Microscopy Sciences. Under dissecting microscope, $1 \mathrm{~mm} \times 1 \mathrm{~mm} \times 3 \mathrm{~mm}$ tissue strips containing SNc and VTA regions were dissected from each side of brain and substantia nigra pars reticulata $(\mathrm{SNr})$ region was discarded. Then blocks were processed by osmium tetroxide, dehydrated, and embedded in Epoxy resin. The $70 \mathrm{~nm}$ sections were cut and examined under Tecnai F30 scanning transmission electron microscope.

For postembedding immunogold EM, mice were perfused with $4 \%$ PFA and $1.5 \%$ glutaraldehyde in PBS, pH 7.4. SNc and VTA tissues were dissected as above and postfixed for $1 \mathrm{~h}$ before embedding. The $80 \mathrm{~nm}$ sections were cut and mounted on formvar-coated 200 mesh nickel grids. A rabbit polyclonal human $\alpha$-synuclein (1:100, Enzo Life Sciences) and a mouse monoclonal anti-OxPhos Complex IV Subunit I (COX1, 1:200, Invitrogen) were used. A $15 \mathrm{~nm}$ gold particle-conjugated anti-rabbit secondary antibody and $10 \mathrm{~nm}$ gold particle-conjugated anti-mouse secondary antibody (Electron Microscopy Sciences) were used to visualize the antigens. Stained sections were examined under Tecnai F30 scanning transmission electron microscope.

\section{HPLC assessment of brain tissue contents of DA and} other neurotransmitters

Dissected striata of adult mice were stored at $-80^{\circ} \mathrm{C}$ until use. The contents of DA, DOPAC, homovanillic acid (HVA), serotonin (5-HT), 5-hydroxyindoleacetic acid (5-HIAA), and norepinephrine (NE) were measured by HPLC through Pronexus Analytical AB (Solna, Sweden), a contract research organization. The HPLC assessment was performed by experimenters blind to genotypes of transgenic mice.

\section{Western blot}

Mice were killed by cervical dislocation. Brains were dissected and cut into $1 \mathrm{~mm}$ slices on Mouse Brain Blocker (David Kopf Instruments) on ice. Tissues from different brain regions (ventral midbrain, striatum, and cortex) were dissected on ice and stored in $-80^{\circ} \mathrm{C}$ until use. Frozen brains were lysed in NTE buffer ( $150 \mathrm{~mm} \mathrm{NaCl}, 50 \mathrm{~mm}$ Tris, $\mathrm{pH}$ 8.0, $5 \mathrm{~mm}$ EDTA, 0.25 mM PMSF, 1\% protease inhibitor mixture, Sigma; 1\% SDS), and $50 \mu \mathrm{g}$ protein was subjected to SDS-PAGE. Proteins were electrophorectically transferred to PVDF membrane and nonspecific sites blocked in 5\% nonfat dry milk in TBS ( $135 \mathrm{~mm} \mathrm{NaCl}, 2.5 \mathrm{~mm} \mathrm{KCl}, 50 \mathrm{~mm}$ Tris, $0.1 \%$ Tween 20, pH 7.4). Membranes were then incubated with various primary antibodies in TBS with $5 \%$ nonfat dry milk: rabbit polyclonal anti-mouse TH antibody (1:2000, Pel-Freez), rabbit polyclonal $\alpha$-synuclein (1:1000, Cell Signaling Technology), mouse monoclonal $\alpha$-synuclein (SYN1) (1:2000, BD Transduction Laboratories), rabbit polyclonal human $\alpha$-synuclein (1:1000, Enzo Life Sciences), mouse monoclonal human $\alpha$-synuclein (SYN211) (1:2000, Santa Cruz Biotechnology), and mouse anti-mouse GAPDH antibody (1:200,000, Abcam). Signals were then detected by HRP-conjugated secondary antibodies (Jackson ImmunoResearch Laboratories) and enhanced chemiluminescence (Pierce).

\section{Behavioral studies}

All mice were kept on a 06:00-18:00 light cycle with ad libitum food and water. Behavioral tests were performed during the light period. The behavioral studies were performed by experimenters blind to genotypes and treatments of transgenic mice.

Open field test. Each mouse was placed in an open field chamber $(40 \mathrm{~cm}$ long $\times 40 \mathrm{~cm}$ wide $\times 37 \mathrm{~cm}$ high, Med Associates). Illumination of open filed was set to 20 lux. No background noise was provided. They were monitored by infrared beams that recorded the animal's location and path (locomotor activity) as well as the number of rearing movements (vertical activity). Data were collected in 5 min trials for 6 trials, and the average was reported.

Rotarod test. Mice were first trained to stay on the rod of the rotarod (Columbus Instruments) at a constant speed of $5 \mathrm{rpm}$ for at least $1 \mathrm{~min}$. After training, mice were tested for a total of three trials with an accelerating speed of $0.2 \mathrm{rpm} / \mathrm{s}$, starting at $5 \mathrm{rpm}$. The latency to fall was recorded for each trial, and the average of three trials was reported.

Gait analysis. Gait pattern was studied using DigiGait gait analysis system (Mouse Specifics). Stride length $(\mathrm{mm})$, stance $(\mathrm{mm})$, and swing $(\mathrm{mm})$ were measured for each paw. The treadmill speed was set to 20 $\mathrm{cm} / \mathrm{s}$ and recoded for $5 \mathrm{~s}$. The $3 \mathrm{~s}$ video was analyzed. Stride is defined as the length of belt movement as the cycle of body movements that begins with the contact of one paw and ends when the same paw again contacts the belt. Stance phase is defined as the length of belt movement while the paw stands on the belt. Swing phase is defined as the length of belt movement while the paw is in the air.

\section{Data analysis}

Data were analyzed using StatView 5.0.1. Data are presented as mean \pm SEM. Unpaired two-tailed Student's $t$ test was used when genotype was the only grouping variable. ANOVA was used when genotype was not the only grouping variable and when data were collected in a single trial.

\section{Results \\ $\alpha$-Synuclein A53T overexpression in DA neurons via controlled genetic amplification}

Missense mutations of $\alpha$-synuclein, including A53T mutant, and duplication/triplication of $\alpha$-synuclein have been causally linked to familial PD (Polymeropoulos et al., 1997; Singleton et al., 2003; Chartier-Harlin et al., 2004). To model gain of function, we have designed a novel cell type-specific "PF" strategy to overexpress human $\alpha$-synuclein A53T in DA neurons under the transcriptional control of the endogenous DAT promoter and generated a DAT-"PF"-tTA driver line (DAT-PF-tTA) (Fig. $1 A, B$ ) (see Materials and Methods).

The DAT-PF-tTA driver line was crossed with a Tet operator (tetO) responder mouse line, tetO-human $\alpha$-synuclein A53T (tetO-SYN) (Lin et al., 2009). The double-transgenic ( $\mathrm{DA}_{\mathrm{SYN} 53}$ ) mice did not have detectable transgenic $\alpha$-synuclein protein expression at 1 week after birth, later than endogenous DAT expression (E15-E17), suggesting that the transgene amplification through "PF" may increase gradually. This postnatal transgenic $\alpha$-synuclein expression works to our advantage as it avoids complications in phenotype interpretation due to early developmental effects of the transgene overexpression, especially during embryonic development. At 6 weeks, the $\mathrm{DA}_{\text {SYN53 }}$ mice had transgenic $\alpha$-synuclein expression in $>95 \%$ DA neurons in midbrain, detected by human-specific SYN-211 antibody (Fig. 1C). In addition, transgenic $\alpha$-synuclein expression was also detected in other DA neuron groups in addition to SNc and VTA, including retrorubral area, hypothalamus, and olfactory bulb, but not in non-DA neurons, such as the locus ceruleus (data not shown), suggesting that the "PF" cassette-mediated gene amplification was well under the control of endogenous DAT promoter. Transgenic $\alpha$-synuclein expression was also seen in cerebellum of both tetO-SYN single-transgenic mice and $\mathrm{DA}_{\mathrm{SYN} 53}$ double-transgenic mice, consistent with the reported leaky expression in limited tissues at low levels, which is tTA-independent in the tetO-SYN singletransgenic line (Lin et al., 2012).

Using an antibody recognizing both human and mouse forms of $\alpha$-synuclein, we estimated that $\alpha$-synuclein transgene expression level was fivefold of the endogenous $\alpha$-synuclein in nigral tissue homogenate (Fig. 1D). Because transgenic $\alpha$-synuclein ex- 


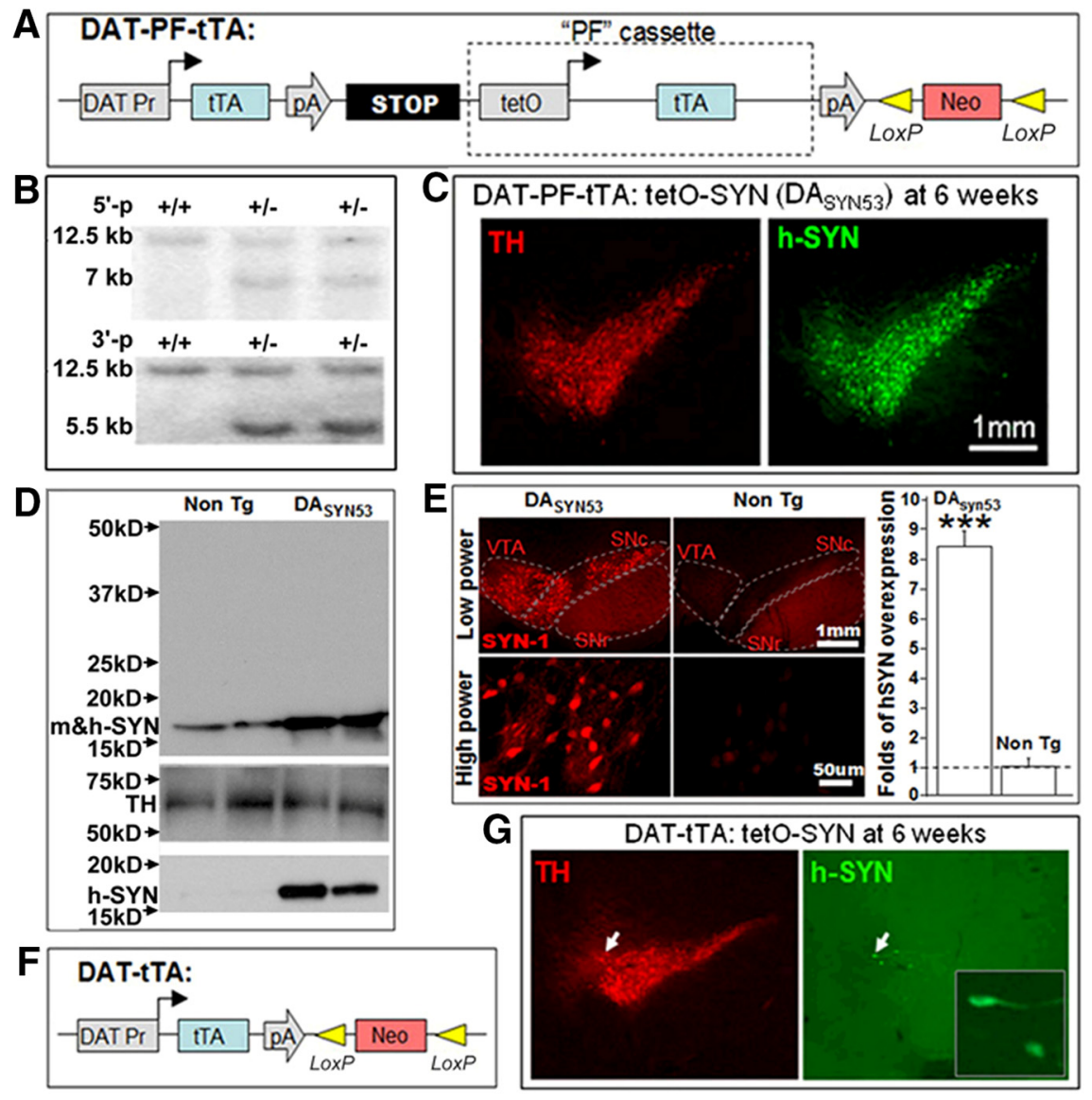

Figure 1. Transgene overexpression in DA neurons using a "PF" cassette targeted to the DAT locus. $A$, A new DAT-tTA line, DAT-PF-tTA, was generated by inserting a tTA-polyA cassette, a stop sequence, and a "PF" cassette (dashed box) immediately after the endogenous DAT promoter by gene targeting. $B$, Southern blot using ES cell genomic DNA identified the correctly targeted ES cell clones for the DAT-PF-tTA line. $5^{\prime}$ probe (top) and 3 ' probe (bottom) outside of targeting arms detected the expected $7 \mathrm{~kb}$ and $5.5 \mathrm{~kb}$ mutant bands and verified successful homologous recombination for both left and right targeting arms. C, The DAT-PF-tTA line was crossed with a tet0-human- $\alpha$-synuclein-A53T line and generated a double-transgenic line, $\mathrm{DA}_{\text {SYN53. }} . \mathrm{DA}_{\text {SYN53 }}$ had strong expression of the transgenic $\alpha$-synuclein in $>95 \%$ of midbrain DA neurons, detected by a human $\alpha$-synuclein-specific antibody SYN211. $\boldsymbol{D}$, Western blot determined that $\mathrm{DA}_{\mathrm{SYN} 53}$ mice had transgenic $\alpha$-synuclein overexpression fivefold of the endogenous mouse $\alpha$-synuclein in midbrain tissue homogenates using an antibody (Cell Signaling Technology) recognizing both mouse and human $\alpha$-synuclein, compared with nontransgenic control mice (top) $(n=3$ mice, $p<0.001)$. TH was used as a loading control for the equal loading of midbrain tissue lysate (middle). Transgenic $\alpha$-synuclein protein expression in DA ${ }_{5 Y N 53}$ mice, but not in nontransgenic control mice, was detected by a human $\alpha$-synuclein-specific antibody SYN211 (bottom). $\boldsymbol{E}$, Measuring transgenic $\alpha$-synuclein expressions in DA neurons by immunofluorescence revealed higher expression (eightfold) detected by SYN1 antibody recognizing both mouse and human $\alpha$-synuclein (50 DA neurons in each genotype were individually measured, $p<0.001$, bar graph). The lower-power pictures represent the drastic difference of $\alpha$-synuclein staining intensity in midbrain DA neurons of $\mathrm{DA}_{\text {SYN53 }}$ and control mice. The boundaries of SNc, VTA, and SNr were delineated. Of note, endogenous mouse $\alpha$-synuclein, enriched in striatonigral terminals in $\mathrm{SNr}$, was strongly stained in both mice by SYN1 antibody, which was absent when stained with a human $\alpha$-synuclein-specific antibody SYN211 (C). ${ }^{* * *} p<0.001 . F$, A DAT promoter-driven TTA line (DAT-tTA) without the "PF" cassette was previously generated in our laboratory by inserting tTA-polyA cassette after endogenous DAT promoter. G, DAT-tTA: tet0-SYN double-transgenic mice only had weak transgenic $\alpha$-synuclein expression in $<1 \%$ midbrain DA neurons (arrow, enlarged in inset), detected by SYN211 antibody. The exposure time of human $\alpha$-synuclein (green) was purposely extended to visualize otherwise very weak staining signal of human $\alpha$-synuclein.

pression was restricted to DA neurons in the midbrain, we were able to quantify its expression in individual DA neurons by immunofluorescence. We estimated that overexpression was eightfold of endogenous $\alpha$-synuclein expression in DA neurons (Fig. 1E). To our knowledge, the level of $\alpha$-synuclein overexpression in DA neurons of $\mathrm{DA}_{\mathrm{SYN} 53}$ mice is among the highest compared with existing $\alpha$-synuclein transgenic mice (Chesselet, 2008; Kuo et al., 2010; Lin et al., 2012).

To determine the effectiveness of amplification by the "PF" mechanism, a DA neuron-specific tTA line without the "PF" cas- sette (DAT-tTA), but otherwise identical to the DAT-PF-tTA (Fig. 1F) (Cagniard et al., 2006), was crossed with the same tetOSYN responder line. The double-transgenic mice (DAT-tTA:tetO-SYN) only showed detectable transgenic $\alpha$-synuclein expression in a fraction of DA neurons (Fig. 1G), supporting the effectiveness of the "PF" strategy in amplifying transgene expression in DA neurons.

\section{Time course of DA neuron} degeneration in $\mathrm{DA}_{\mathrm{SYN} 53}$ mice Both $\alpha$-synuclein gene multiplication and A53T point mutations are causal for lateonset PD (Polymeropoulos et al., 1997; Singleton et al., 2003; Chartier-Harlin et al., 2004). We asked whether overexpression of the human A53T $\alpha$-synuclein in DA neurons in the $\mathrm{DA}_{\mathrm{SYN} 53}$ mice is sufficient to cause DA neuron degeneration. At 6 weeks, there was no obvious midbrain DA neuron loss in $\mathrm{DA}_{\mathrm{SYN} 53}$ mice. At 3 months, there was $\sim 21 \%$ DA neuron loss and at 6 months there was $\sim 35 \%$ DA neuron loss in $\mathrm{SNc}$ of $\mathrm{DA}_{\mathrm{SYN} 53}$ mice compared with wild-type (Fig. 2A). There was no significant difference of DA neuron number in $\mathrm{SNc}$ between wild-type, tetOSYN and DAT-PF-tTA mice (Fig. 2A), suggesting that the observed DA neuron loss in $\mathrm{DA}_{\mathrm{SYN} 53}$ mice was specifically induced by human $\alpha$-synuclein A53T mutant expression. However, the DA neuron loss appeared to slow down significantly or stopped between 6 and 12 months (Fig. $2 A$ ). Whether there will be much more severe DA neuron loss in even older mice remains to be determined. At 12 months, the decrease of total Nissl-positive neurons in SNc was comparable with DA neuron loss at this age, indicating that the decreased TH-positive neuron counting was due to the actual DA neuron loss but not loss of TH phenotype (Fig. 2A). The loss of DA neurons in $\mathrm{SNc}$ appeared not to be restricted to specific tiers of SNc. We were unable to determine DA neurons loss in the VTA because abundant fibers interfere with accurate determination of DA neuron in this region (see Materials and Methods). Instead, we examined TH staining intensity in the dorsal and ventral striata of $\mathrm{DA}_{\mathrm{SYN} 53}$ and control mice as an estimate of DA neuron striatal terminal loss. Obvious striatal TH terminal staining signal decrease started at 3 months. At 12 months, there was a 39\% TH terminal staining decrease in the dorsal striatum. In contrast, there was no obvious $\mathrm{TH}$ terminal staining decrease in the ventral striatum (Fig. 2B), suggesting DA neurons in VTA may be spared.

We further examined the neurochemical changes by HPLC in dorsal striatum of 12-month-old $\mathrm{DA}_{\mathrm{SYN} 53}$ and control mice. DA in striatal tissue lysate, reflecting its intracellular vesicular stor- 

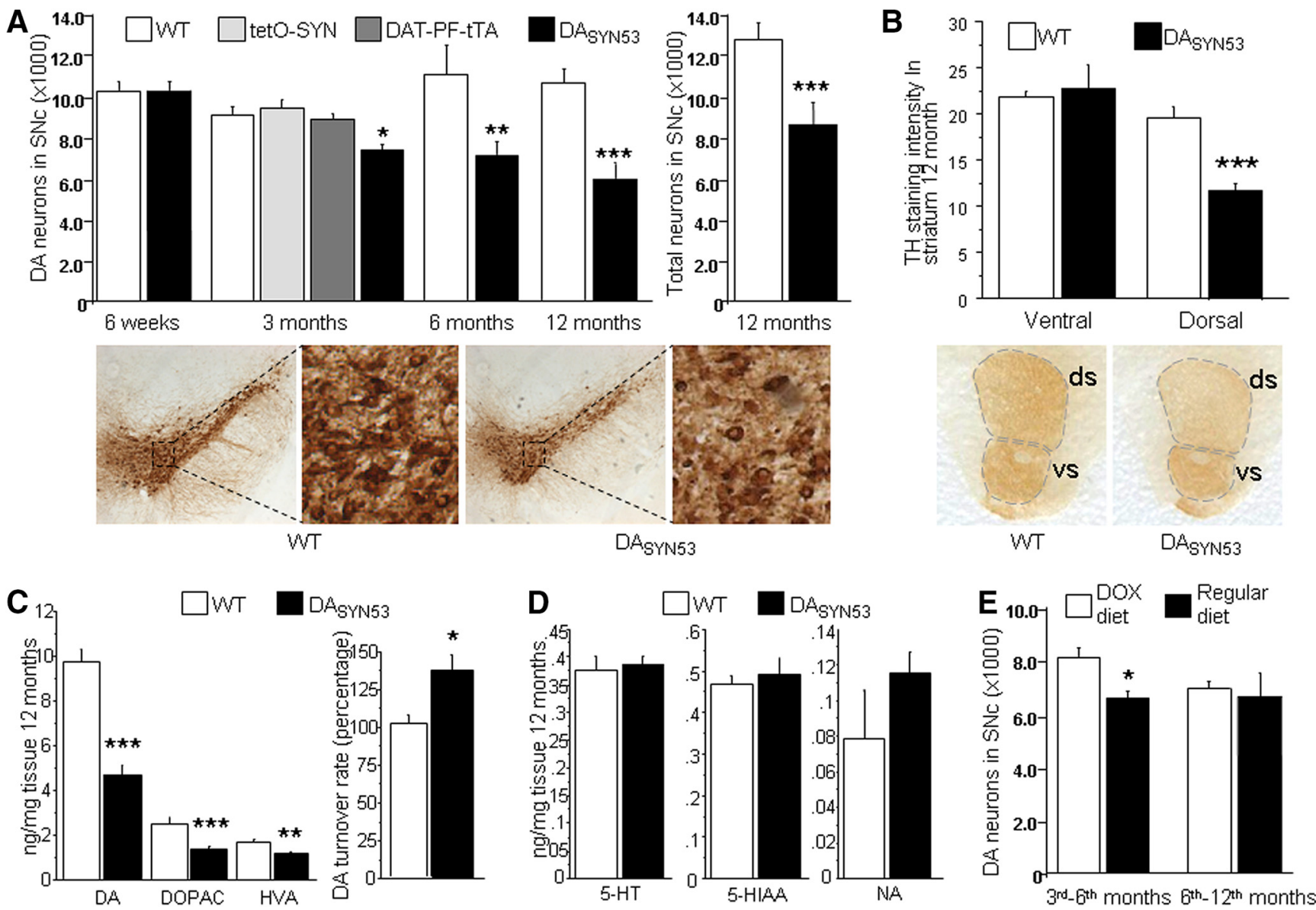

Figure 2. DA neurons degeneration in $\mathrm{DA}_{\mathrm{SYN} 53}$ mice. $A$, The DA neuron number in $\mathrm{SN}$ c of 6 week, 3,6 , and 12 month mice were determined by a design-based unbiased stereological cell counting. At 6 weeks, there was no obvious midbrain DA neuron loss in $\mathrm{DA}_{\text {sYN53 }}$ mice $(n=6)$. There were $20 \%, 37 \%$, and $35 \%$ DA neuron loss at 3, 6, and 12 months, respectively, compared with wild-type mice $(n=6-8, p<0.05, p<0.01, p<0.001)$. Stereology counting of Niss--positive neurons in SNc at 12 months revealed a comparable loss of total neurons $(n=6, p<0.001)$. Representative pictures show DA neuron loss in $\mathrm{SN}$ of 12-month-old $\mathrm{DA}_{\mathrm{SYN53}}$ mice. $\boldsymbol{B}, \mathrm{DA}_{\mathrm{SYN} 53}$ mice at 12 months displayed loss of $\mathrm{TH}$ staining preferentially in dorsal striatum. TH staining in dorsal striatum was decreased by $42 \%$ ( $n=6-8$ mice, at least 10 striatal sections were assessed from each mouse, $p<0.001)$ but unchanged in ventral striatum $(n=6-8$ mice, at least 10 striatal sections were assessed from each mouse, $p>0.05$ ). The representative pictures show the preferential loss of TH staining in dorsal striatum. The lightly stained dorsal striatum sections were purposely chosen to keep the staining intensity within the linear range for more accurate measurements. The boundaries of dorsal striatum and ventral striatum are delineated. ds, Dorsal striatum; vs, ventral striatum. C, The striatal tissues of 7-11 month mice ( $n=12-16$, gender-, genotype-, and age-matched) were dissected. DA and its metabolites were measured by HPLC for DA $A_{\text {SYN53 }}$ and control mice (wild-type, tet0-SYN, and DAT-PF-tTA single-transgenic mice). Striatal tissue content of DA was decreased by $54 \%$ in DA $A_{\text {SYN53 }}$ mice $(p<0.001,9.965 \pm 0.543 \mathrm{vs} 4.650 \pm 0.411 \mathrm{ng} / \mathrm{mg}$ wet tissue, mean \pm SEM). DA metabolites, DOPAC and HVA, were also decreased by $45 \%(p<0.001,2.288 \pm 0.285$ vs $1.241 \pm 0.119 \mathrm{ng} / \mathrm{mg}$ wet tissue, mean \pm SEM) and $31 \%$ ( $p<0.01,1.673 \pm 0.1 \mathrm{vs}$ $1.146 \pm 0.101 \mathrm{ng} / \mathrm{mg}$ wet tissue, mean \pm SEM). The DA turnover rate was increased by $29 \%$ measured as the ratio of (DOPAC $+\mathrm{HVA}) / \mathrm{DA}(p<0.05,0.409 \pm 0.038 \mathrm{vs} 0.527 \pm 0.033$, mean \pm SEM). $\boldsymbol{D}$, The other neurotransmitters in striatal tissues were unchanged in $D_{\text {SYN53 }}$ mice, serotonin $(5-\mathrm{HT})(p>0.05,0.376 \pm 0.024$ vs $0.383 \pm 0.016 \mathrm{ng} / \mathrm{mg}$ wet tissue, mean \pm SEM), its metabolite 5 -HIAA $(p>0.05,0.468 \pm 0.021$ vs $0.486 \pm 0.041 \mathrm{ng} / \mathrm{mg}$ wet tissue, mean $\pm \mathrm{SEM})$, and NE $(p>0.05,0.079 \pm 0.027 \mathrm{vs} 0.114 \pm 0.011 \mathrm{ng} / \mathrm{mg}$ wet tissue, mean $\pm \mathrm{SEM})$. $E$, Suppressing the transgene expression by DOX treatments reduced DA neuron loss in young $D_{5 Y N 53}$ mice. One cohort of 3-month-old DA $A_{5 Y N 53}$ mice ("third-sixth months" on the left) were divided into two groups. One group was administrated with the DOX diet ( $200 \mathrm{mg} / \mathrm{kg}$ ) for 3 months and another group was kept on regular laboratory chow. These mice were killed at the age of 6 months. The DA neuron loss was significantly reduced by the DOX treatment $(p<0.05, n=7)$. In addition, a 6 month DOX treatment was given to older DA syns3 $_{3}$ mice starting at the age of 6 months ("sixth-12th months" on the right). These older mice were killed at the age of 12 months. The DOX treatment had no effect on DA neuron number in this older cohort $(n=6) .{ }^{*} p<0.05 .{ }^{* *} p<0.01 .{ }^{* * *} p<$ 0.001 .

age, was decreased by $54 \%$ in $\mathrm{DA}_{\mathrm{SYN} 53}$ mice. DA metabolites, DOPAC and HVA, were also decreased by $45 \%$ and $31 \%$, respectively. The DA turnover rate, measured as the ratio of (DOPAC + HVA)/DA, was increased by $29 \%$ (Fig. 2C), suggesting compensatory upregulation of DA neuron activity. Other neurotransmitters and their metabolites, including 5-HT, 5-HIAA, and NE, remained unchanged in the striatum (Fig. 2D).

To further confirm the observed DA neuron loss in $\mathrm{DA}_{\mathrm{SYN} 53}$ mice was specifically induced by human $\alpha$-synuclein A53T mutant expression, DOX treatments were administrated to $\mathrm{DA}_{\mathrm{SYN} 53}$ mice to suppress the transgene expression. DOX treatment administered to younger mice ( 3 months old) significantly reduced DA neuron loss, further supporting that the DA neuron loss was induced by the transgene expression. However, DOX treatments of older mice (6 months old) did not affect the DA neuron loss, consistent with the aforementioned observation that DA neurons did not degenerate further between 6 months and 12 months (Fig. 2E).

Despite significant loss of DA neuron and tissue DA content, $\mathrm{DA}_{\mathrm{SYN} 53}$ mice appeared grossly normal and no obvious locomotion impairment was observed in the open field (Fig. $3 A-D$ ). Nine-month-old male mice $(n=10)$ were also tested for gait pattern using DigiGait. Even though the DigiGait analysis sensitively detected the different preference of hind and front paws for stance and swing phases, there were no genotype differences in stride, stance phase, or swing phase (Fig. $3 E-G$ ). These findings are 

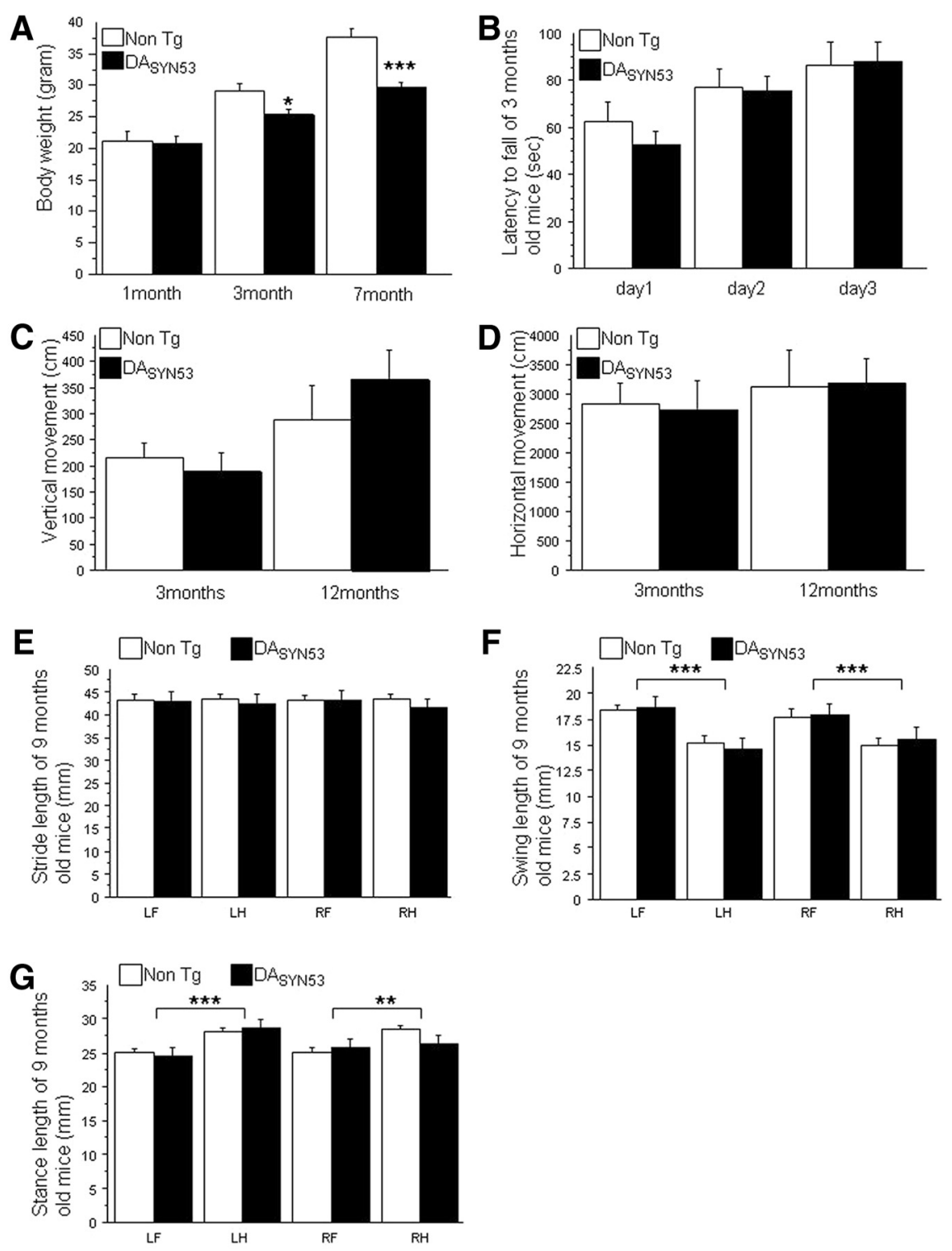

Figure 3. $\mathrm{DA}_{\mathrm{SYN} 53}$ mice displayed slower body weight gain but normal locomotion and gait pattern. $A$, The body weights of 3 cohorts of male mice $(n=10-15)$ at 1,3 , and 7 months were measured. $D_{\text {SYN53 }_{3}}$ mice displayed slower body weight gain in an age-dependent manner. The lower body weight of $\mathrm{DA}_{\text {SYN53 }}$ mice was apparent at 3 months of age $(13.8 \%, p<0.05)$ and more pronounced at 7 months of age $(22.4 \%, p<0.001)$, with a significant age $\times$ genotype interaction for body weight $(p<0.01)$. $\boldsymbol{B}$, Three-month-old male mice $(n=10)$, the same age cohort as in A, had normal latency-to-fall in a Rotarod test for three consecutive days. $C, D$, Neither 3- nor 11-month-old DA SYN53 $_{3}$ mice developed abnormal horizontal, vertical locomotion in 30 min open field tests $(n=8-15) . \mathbf{E}, \boldsymbol{F}, \mathbf{G}$, Nine-month-old male mice $(n=10)$ were tested for gait pattern using DigiGait gait analysis system. Stride length $(\mathrm{mm})$, stance $(\mathrm{mm})$, and swing $(\mathrm{mm})$ were measured for each paw. Even though the DigiGait analysis sensitively detected the different preference of hind and front paws for stance and swing phases, there was no genotype difference for the three parameters measured. ${ }^{*} p<0.05 .{ }^{* *} p<0.01 .{ }^{* * *} p<0.001$.

consistent with the general observation that $>80 \%$ chronic DA neuron loss is required for obvious motor symptoms in $\mathrm{PD}$ patients (Dauer and Przedborski, 2003).

\section{Formation of intracellular inclusions of mitochondria origin in DA neurons}

Mitochondria impairments are central in PD pathogenesis (Schon and Przedborski, 2011). Postmortem studies indicate dramatically reduced mitochondria activities and high-level mtDNA deletion in the substantia nigra of PD patients (Schapira et al., 1989; Shults et al., 1997; Bender et al., 2006; Keeney et al., 2006). Moreover, mitochondria complex I inhibitors, such as
MPTP, are well documented to cause DA neuron degeneration and PD symptoms in humans (Langston et al., 1983; Dauer and Przedborski, 2003).

Having found DA neuron degeneration in $\mathrm{DA}_{\mathrm{SYN} 53}$ mice, we next characterized subcellular pathologies in DA neurons. Starting weeks after birth, the most striking pathologies were numerous intraneuronal inclusions strongly labeled by mitochondrial markers COX1 (mitochondrial complex IV, subunit 1) and SOD2 (manganese SOD) (Fig. $4 A, E$ ), indicating that mitochondria contribute to the formation of these inclusions. Double fluorescence staining revealed that transgenic $\alpha$-synuclein was partially colocalized with, but not enriched within, the inclusions or their surrounding mitochondrial network (Fig. $4 B, D)$. The inclusions were $0.5-2 \mu \mathrm{m}$ in diameter and completely devoid of $\mathrm{TH}$ staining, separating them from the rest of the cytoplasm (Fig. 4C). These intracellular inclusions are referred to as "mitochondrial inclusions" hereafter for their mitochondrial content.

Semiquantitative analysis from a total of 12 sections from 4 mice at 6 weeks estimated that there were $34.2 \pm 5.5$ (mean \pm SD) mitochondrial inclusions per midbrain section (between bregma -2.75 and $-2.92 \mathrm{~mm}$, corresponding to the rostral quarter of SNc and VTA) with an average of one mitochondrial inclusion in every 4.3 DA neurons, although some DA neurons contained more than one mitochondrial inclusion (Fig. 4C-E). Mitochondrial inclusions were mostly restricted within SNc. There were fewer inclusions in the VTA, and they were absent in $\mathrm{SNr}$ and striatum, suggesting DA neuron soma and proximal processes but not distal processes have specific milieu for mitochondrial inclusion formation. Within midbrain, mitochondrial inclusions were distributed in soma and proximal processes of DA neurons in $\mathrm{DA}_{\mathrm{SYN} 53}$ mice but absent in control mice (tetO-SYN single-transgenic, DAT-PF-tTA single-transgenic and wild-type mice) (Fig. $4 F$ ). Consistently, suppressing human $\alpha$-synuclein A53T transgene expression by 3 month DOX treatment led to complete disappearance of mitochondrial inclusions in $\mathrm{DA}_{\mathrm{SYN} 53}$ mice, indicating that the formation of mitochondrial inclusions is specifically induced by the human $\alpha$-synuclein A53T transgene expression (Fig. 4G).

Mitochondria were apparently fragmented at as early as 6 weeks of age (Fig. $5 A, B$ ), an indication of mitochondria impairments and/or inefficient clearance of damaged mitochondria (Twig et al., 2008). Despite the mitochondria fragmentation and the formation of mitochondrial inclusions, DA neurons in $\mathrm{DA}_{\mathrm{SYN} 53}$ mice had normal mitochondria mass as measured by staining intensity of COX1 and SOD2 (Fig. 5B). At the ultrastruc- 
tural level, numerous senescent mitochondria were observed in midbrain neurons. These senescent mitochondria displayed disordered cristae, swollen matrix, and disappearance of outer membranes, in contrast to the morphologically normal mitochondria in neighboring cells (Terman et al., 2006) (Fig. 5C). We further investigated the ultrastructure of the mitochondrial inclusions using postembedding double immunogold electron microscopy for COX1 and transgenic $\alpha$-synuclein. The following criteria were used to identify mitochondrial inclusions: (1) positive for COX1 labeling, (2) their size (1-2 $\mu \mathrm{m}$ in diameter), (3) their presence within transgenic $\alpha$-synuclein labeled DA neurons, and (4) their distinct morphologies from surrounding mitochondria. Under EM, in transgenic $\alpha$-synuclein-positive neurons, these mitochondrial inclusions, in addition to surrounding normal-appearing mitochondria, were specifically labeled with both COX1 and transgenic $\alpha$-synuclein (Fig. $5 D, E)$. The staining specificity was demonstrated in Figure $5 D$. These mitochondrial inclusions contained electron-dense regions, which were composed of densely compacted COX1 positive (identified with $10 \mathrm{~nm}$ gold) double membranes, indicative of mitochondria crista folded with inner membrane. The remainder of the mitochondrial inclusions in addition to the electron-dense regions was composed of less compacted double membranes, which were also COX1-positive (identified with 10 $\mathrm{nm}$ gold) and occupied the majority of mitochondrial inclusions. The above data suggest that these inclusions are composed of mitochondrial remnants (Fig. $5 E, F$ ).

\section{Mitochondrial inclusions precede other DA neuron pathologies}

It is often debated whether frequently observed mitochondria abnormality is a primary cause or a downstream consequence of neurodegeneration (Perier and Vila, 2012). We therefore examined the time course of various pathologies in the $\mathrm{DA}_{\mathrm{SYN} 53}$ mice. At 3 weeks, mitochondrial inclusions were already obvious, although DA neurons appeared normal otherwise (Fig. 6A). Quantification of mitochondrial inclusions indicated significantly more mitochondrial inclusions at 3 weeks (1.6 \pm 0.3 mitochondria inclusions/DA neuron) than 6 weeks $(0.23 \pm$ 0.04 mitochondrial inclusion/DA neuron) in $\mathrm{DA}_{\mathrm{SYN} 53}$ mice (Fig. $6 C, p<0.001$ ). At 6 weeks, despite fewer mitochondrial inclusions, $\mathrm{DA}_{\mathrm{SYN} 53}$ mice developed other obvious DA neuron pathologies (Fig. 6B). These DA pathologies include significantly decreased $\mathrm{TH}$ staining intensity in striatum (Fig. 6B, quantified in Fig. 6C), 25-fold increase of enlarged var-
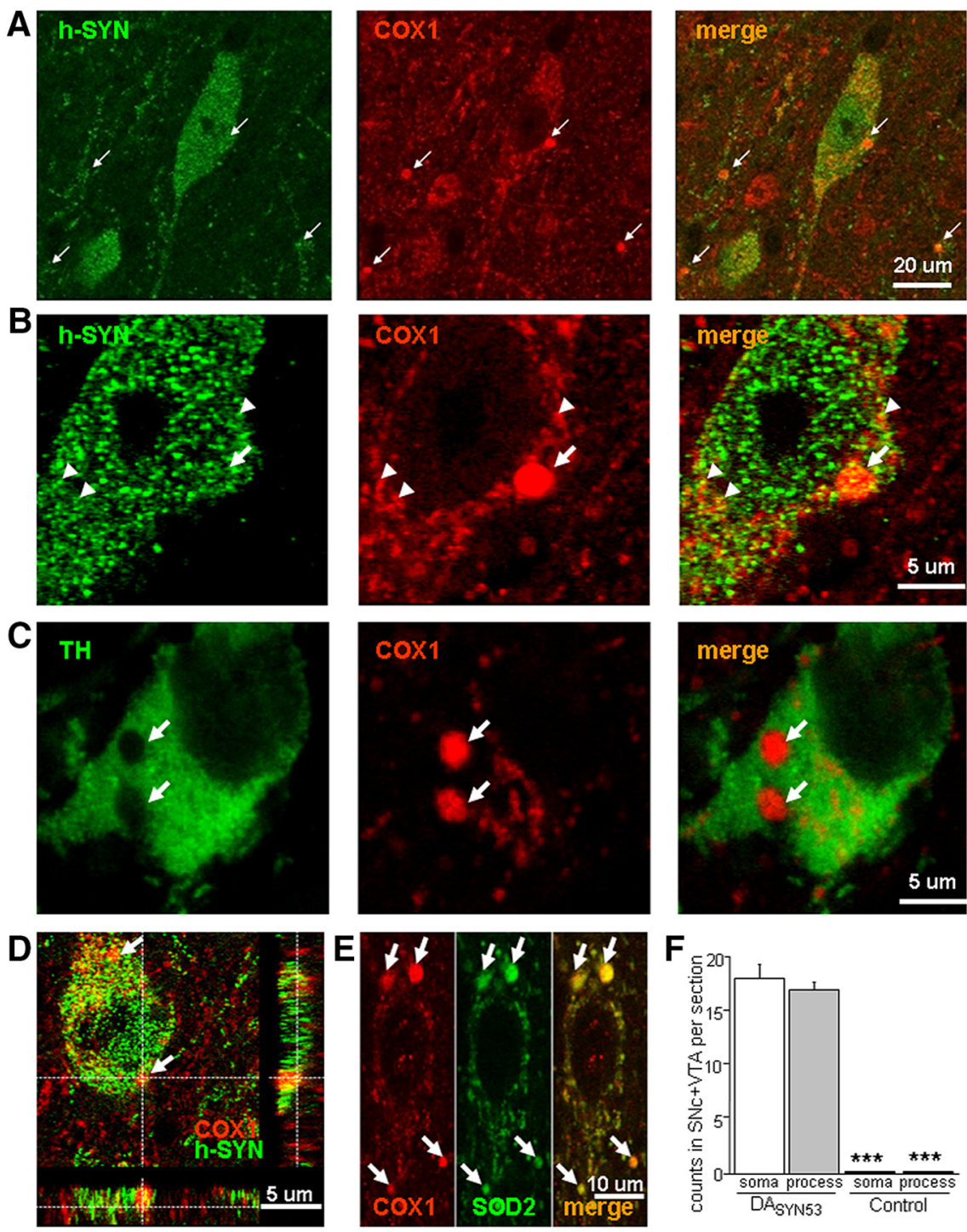

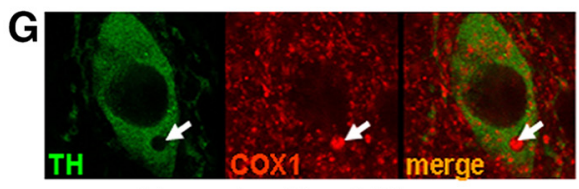

DAsmss mice without DOX treatment

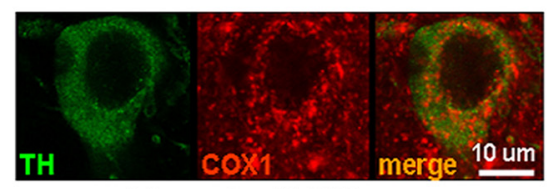

DAsYN53 mice with DOX treatment
Figure 4. Formation of abnormal intracellular mitochondrial inclusions. A, A mitochondrial marker, COX1, revealed abnormal spherical intracellular mitochondrial inclusions (arrow), only in transgenic $\alpha$-synuclein-expressing DA neurons. The size of mitochondrial inclusions was $0.5-2 \mu \mathrm{m}$ in diameter. $\boldsymbol{B}, \mathrm{A}$ high-magnification view of a mitochondrial inclusion in transgenic $\alpha$-synuclein-expressing neurons. Transgenic $\alpha$-synuclein displayed punctate staining pattern in soma and was colocalized, but not enriched, within mitochondrial inclusion (arrow). In addition, transgenic $\alpha$-synuclein was partially colocalized with mitochondria (arrowhead). C, Mitochondrial inclusions had no colocalization with TH (arrow). D, Confocal orthogonal sectioning confirmed the intracellular localization of mitochondrial inclusions (arrow) within transgenic $\alpha$-synuclein-expressing neurons. $\boldsymbol{E}$, The mitochondrial inclusions (arrow) were also positively labeled with another mitochondria marker, Mn-SOD (SOD2), confirming their mitochondrial origin. $\boldsymbol{F}$, Within midbrain, mitochondrial inclusions were equally present in DA neuron soma and processes of $\mathrm{DA}_{\text {SYN53 }}$ mice $(n=3$ mice, $p<0.001)$. ${ }^{* * *} p<0.001$. G, Clearance of mitochondrial inclusions after suppressing human $\alpha$-synuclein A53T mutant transgene expression by 3 month dietary D0X treatments. Three-month-old DA $A_{\text {SYN53 }}$ mice were treated with $200 \mathrm{mg} / \mathrm{kg}$ DOX diet for 3 months and were then killed at 6 months of age to assess the mitochondrial inclusions. Mitochondrial inclusions were not observed in the DOX-treated $\mathrm{DA}_{\text {SYN53 }}$ mice $(n=7$ mice).

icosities in the midbrain region (more abundant in the rostral quarter of $\mathrm{SNc}$ ), and fragmented dendrites in $\mathrm{SNr}$ (Fig. $6 \mathrm{~B}$, quantified in Fig. $6 C$ ). The above pathologies persisted at 12 months, the oldest age examined. The abnormally enlarged varicosities did not contain mitochondrial inclusions. These enlarged 

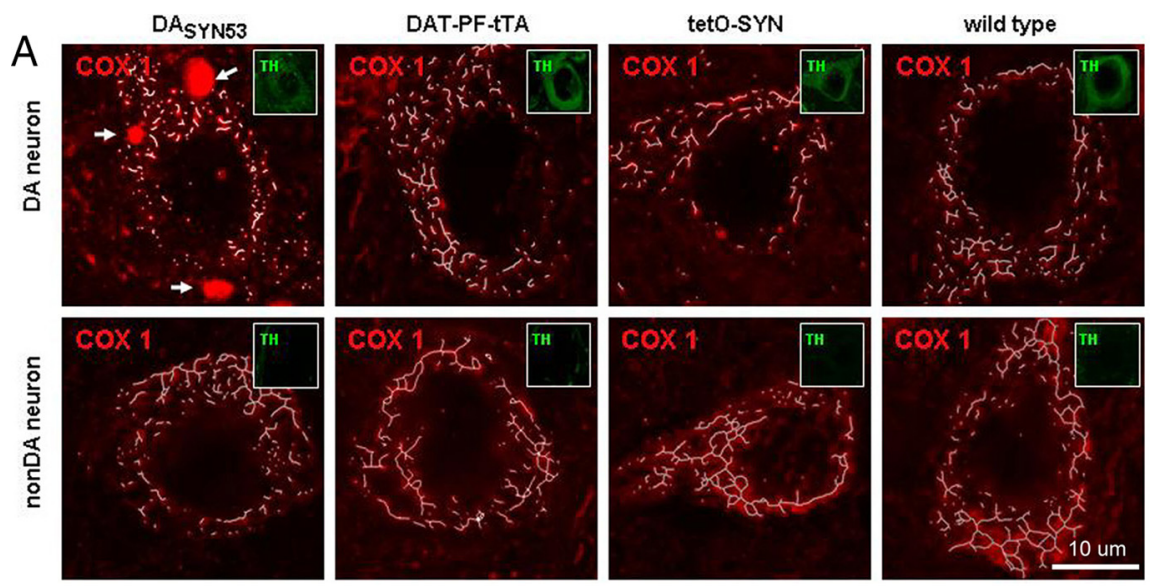

B

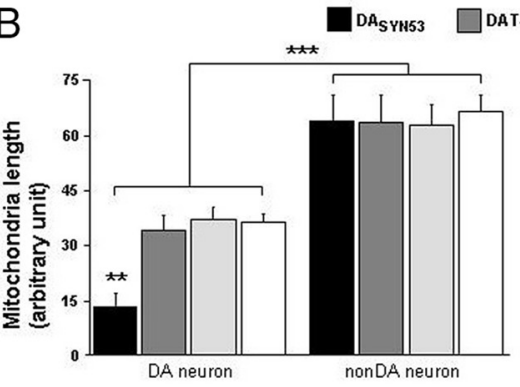

\begin{abstract}
$\square$ teto-SYN $\square$ Wild type
\end{abstract}
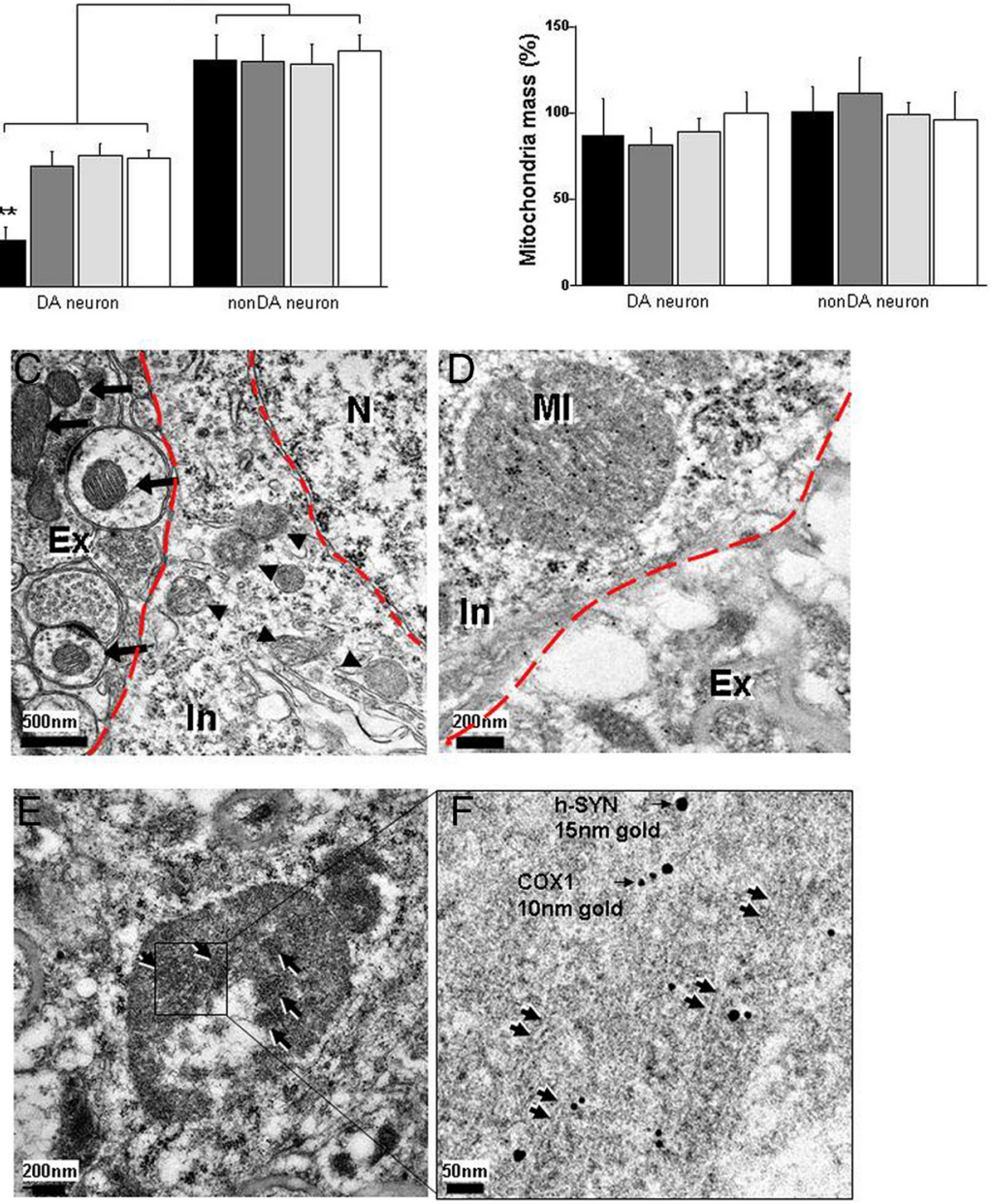

Figure 5. Mitochondrial inclusions contained mitochondrial remnants. $\boldsymbol{A}$, Mitochondria (COX1, red) were apparently fragmented in DA neurons ( $\mathrm{TH}$, green, shown in insets) of $\mathrm{DA}_{\mathrm{SYN} 53}$ mice, compared with mitochondria staining in DA neurons in control mice and non-DA neurons in all genotypes. Mitochondrial inclusions were only observed in DA neurons of DA $A_{\text {YYN53 }}$ mice (white arrow). Skeletonized mitochondria (white lines and dots) were overlaid. Three mitochondrial inclusions were observed in the picture (white arrow). $\boldsymbol{B}, \mathrm{DA}$ neurons of $\mathrm{DA}_{\mathrm{SYN} 53}$ mice had $61 \%$ reduction of average mitochondria length (left, $n=10$ neurons from 3 mice, $p<0.001$ ) compared with those of control mice, an indication of mitochondria fragmentation, whereas mitochondria staining intensity (excluding mitochondrial inclusions) revealed by COX1 and SOD2 staining was unchanged (right, $n=100$ neurons from 3 mice). Interestingly, DA neurons of all genotypes showed significant short average mitochondria length compared with non-DA neurons ( $n=10$ neurons from 3 mice). ${ }^{* *} p<0.01$. ${ }^{* *} p<0.001$. C, Conventional electron microscopy revealed apparent ultrastructural abnormalities of mitochondria in midbrain neurons of $\mathrm{DA}_{\mathrm{SYN53}}$ mice. These senescent mitochondria showed the disordered cristae, swollen matrix, and disappearance of outer membranes (arrowhead). In contrast, mitochondria with normal appearance were found in the neighboring cells (arrow). Cell and nuclear membranes were depicted with long and short dotted lines. N, Nucleus; In, intracellular; Ex, extracellular. D, A typical mitochondrial inclusion was identified with double varicosities were $10 \pm 0.6 \mu \mathrm{m}$ in diameter, oval-shaped, and had a hollowed core. Surrounding the hollowed core, a thin rim $(\sim 1 \mu \mathrm{m}$ in thickness) stained positive for both $\mathrm{TH}$ and transgenic human $\alpha$-synuclein (data not shown).

\section{Mitochondrial inclusion formation is caused by mitochondria-specific macroautophagy}

The selective elimination of mitochondria by macroautophagy is an essential mechanism for the clearance of superfluous or damaged mitochondria, which can be parkin/PINK1-dependent or independent (Allen et al., 2013; Fu et al., 2013). The widespread accumulation of damaged mitochondria in the $\mathrm{DA}_{\mathrm{SYN} 53}$ mice prompted us to investigate the involvement of mitochondria-specific macroautophagy in these mice.

In macroautophagy, cargo is sequestered and taken up by autophagosome, which then transports the cargo to the lysosome for degradation. In mammalian systems, an often used marker for autophagosomes is the protein MAP1LC3B (LC3), which is covalently linked to phosphatidylethanolamine of the autophagosome membrane (Klionsky et al., 2012). To examine whether LC3 may be associated with the mitochondrial inclusions, we performed immunolabeling for LC3. Most (>90\%) mitochondrial inclusions were strongly labeled with LC3 (Fig. 7A) and at times appeared encapsulated by LC3 positive membrane-like structures (Fig. 7B). Consistent with the role of ubiquitin in mitophagy, mitochondrial inclusions were also stained positive for ubiquitin (Fig. 7C).

p62/SQSTM1 (p62) is a multifunctional protein acting as an adaptor protein for several types of ubiquitin recognition and selective macroautophagy, including mi-

\section{$\leftarrow$}

immunogold electron microscopy. Dotted line indicates DA neuron cell membrane. A hSYN antibody specifically labeled DA neuron but not non-DA neuron tissues. MI, Mitochondrial inclusions; In, intracellular; Ex, extracellular. $\boldsymbol{E}$, Double immunogold electron microscopy demonstrated that mitochondrial inclusions were specifically double-labeled with both transgenic $\alpha$-synuclein (15 nm gold particles) and COX1 (10 nm gold particles). Within the mitochondrial inclusions shown $(1.8 \times 2.2 \mu \mathrm{m})$, there were several electron-dense areas indicated by black arrows. The clusters appeared composed of densely packed double membranes (arrowhead), which were both COX1- and hSYN-positive. The remainder of the mitochondrial inclusions, in addition to the electron-dense regions, was composed of less compacted double membranes, which were also COX1- and hSYN-positive and occupied the majority of mitochondrial inclusions. $\boldsymbol{F}$, Magnified view of the boxed area of $E$. 

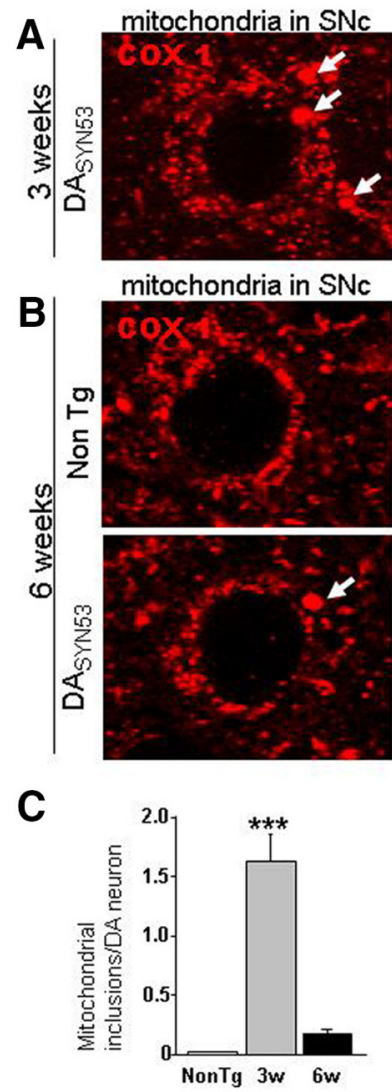
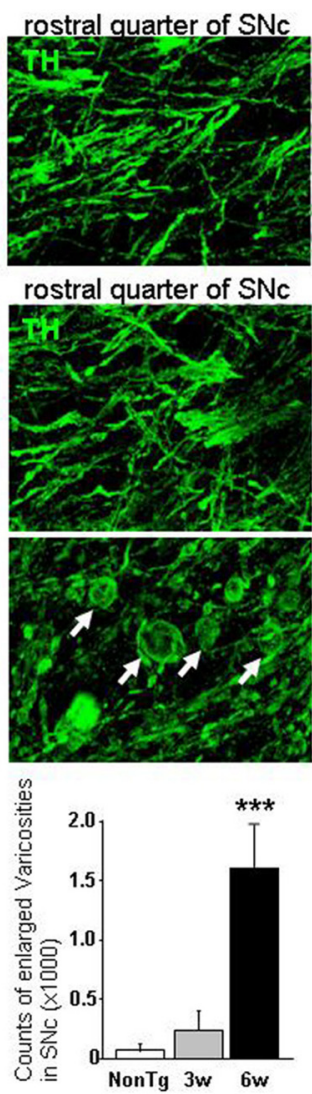

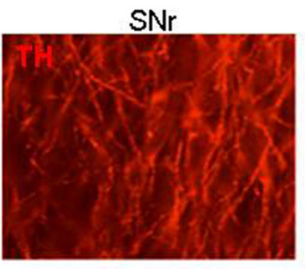

$\mathrm{SNr}$
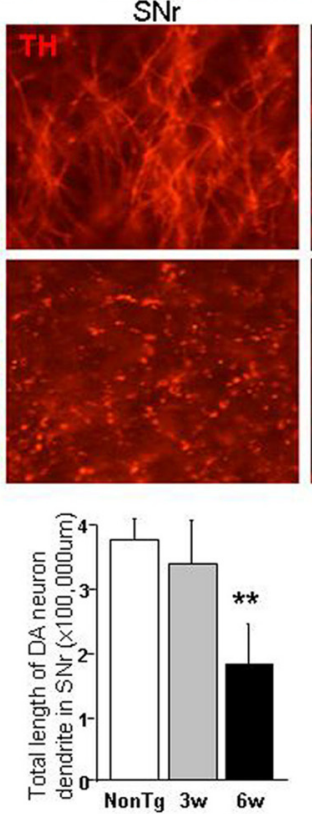

striatum

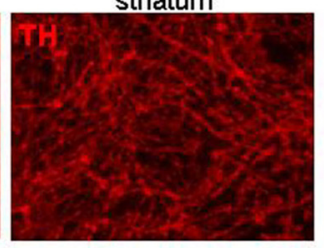

striatum
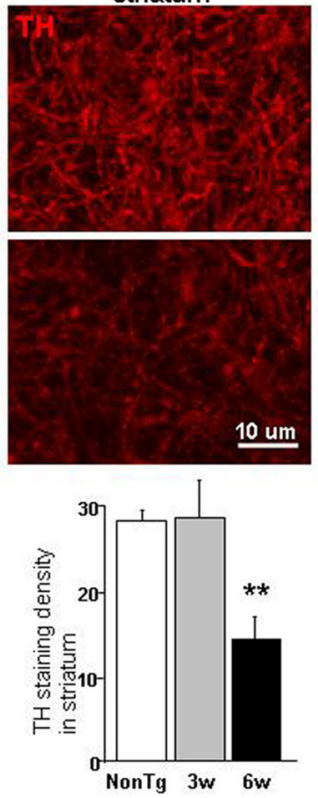

Figure 6. Mitochondrial inclusions preceded other early-onset DA neuron pathologies. $A$, At 3 weeks, mitochondrial inclusions were readily detectable (white arrows). In contrast, no other DA neuron pathologies were obvious. $B$, There were significantly fewer mitochondrial inclusions at 6 weeks than 3 weeks $(0.23 \pm 0.04$ mitochondrial inclusions/DA neuron vs $1.6 \pm 0.3$ mitochondrial inclusions/DA neuron, $p<0.001)$. At 6 weeks, DA neurons developed obvious neuropathologies, including an increase in enlarged axonal varicosity in $S N c$ ( $n=5$ mice, $p<0.001$, white arrows). Fragmented dendrites in $\mathrm{SNr}(n=5$ mice, $p<0.05)$ and decreased TH staining intensity in striatum $(n=5$ mice, $p<0.01)$ were also observed. C, Quantification of DA neuron pathologies in 3-week-old, 6-week-old DA $\mathrm{SYN53}_{3}$ mice and nontransgenic mice. The first column was stained with a COX1 antibody. The last three columns were stained with a TH antibody. NonTg, Nontransgenic control; 3w, 3-week-old DA SYN53 $_{\text {mice; } 6 \mathrm{w}, 6-\text { week-old DA }}$ SYN53 mice. ${ }^{* *} p<0.01$. ${ }^{* * *} p<0.001$.

tophagy (Mathew et al., 2009; Geisler et al., 2010; Johansen and Lamark, 2011; Nezis and Stenmark, 2012). p62 protein level appeared normal in $\mathrm{DA}$ neurons of $\mathrm{DA}_{\mathrm{SYN} 53}$ mice determined by immunofluorescent staining. However, p62 staining revealed numerous ring-like structures within DA neurons (Fig. 7D). All p62-positive rings had mitochondrial inclusions encapsulated within (Fig. $7 E, F$ ), although $<10 \%$ mitochondrial inclusions were encapsulated by p62-positive rings. Interestingly, all the p62 rings that we examined were hollow spheres with an opening on the side, demonstrated by $3 \mathrm{D}$ reconstruction using serial $z$-stack confocal images (Fig. $7 G$ ).

At ultrastructural level, we found senescent mitochondria, showing disappearing outer membranes and disorganized inner membranes, some of which appeared being engulfed by doublemembrane-like structures (Fig. $8 A, B$ ), suggesting that damaged mitochondria were removed by mitophagy. It is unlikely that a mitochondrial inclusion was derived from a single piece of mitochondria. This notion is supported by aforementioned double immunogold labeling of mitochondrial inclusions, which suggests that multiple small mitochondria pieces were compacted to form the mitochondrial inclusions.

It is reported that $\alpha$-synuclein not only impairs mitochondria but also affects other organelles, such as endoplasmic reticulum (ER) and Golgi apparatus (Cooper et al., 2006; Martinez-Vicente et al., 2008; Colla et al., 2012; Guardia-Laguarta et al., 2014). We next asked whether $\alpha$-synuclein overexpression selectively dam- aged mitochondria. In an EM ultrastructural study, we surveyed 150 neurons in SNc region under TEM ( $n=2$ mice). The ER and Golgi were moderately dilated, but there was no evidence for obvious bulk macroautophagy, such as ER and Golgi enclosed by double membranes, despite frequent formation of intracellular vacuoles. The selective mitochondria pathology was further supported by double immunofluorescence studies revealing that the ER and Golgi were neither component of mitochondrial inclusions nor displaying obvious morphological abnormalities (Fig. 8C).

\section{Endogenous parkin or PINK1 is required for mitochondria} homeostasis but not for nonselective mitophagy

The accumulation of abnormal mitochondria, as well as the p62and LC3-positive mitochondrial inclusions, strongly suggests that $\alpha$-synuclein overexpression affects macroautophagic turnover of mitochondria. Two other PD-related proteins, parkin and PINKI, have been previously shown to act in the same functional pathway for mitochondria dynamics in Drosophila (Clark et al., 2006; Park et al., 2006) and play a key role in the selective elimination of damaged mitochondria by mitophagy in CCCP-induced mitophagy mammalian cell culture models (Vives-Bauza and Przedborski, 2011). However, the parkin/PINK1/mitophagy hypothesis is largely based on in vitro cell culture models using nonselective decoupling reagents, such as CCCP. Its relevance to PD still lacks in vivo evidence (Ashrafi and Schwarz, 2013; Grenier et al., 2013). Interestingly, genetic elimination of these two genes in mice did not 

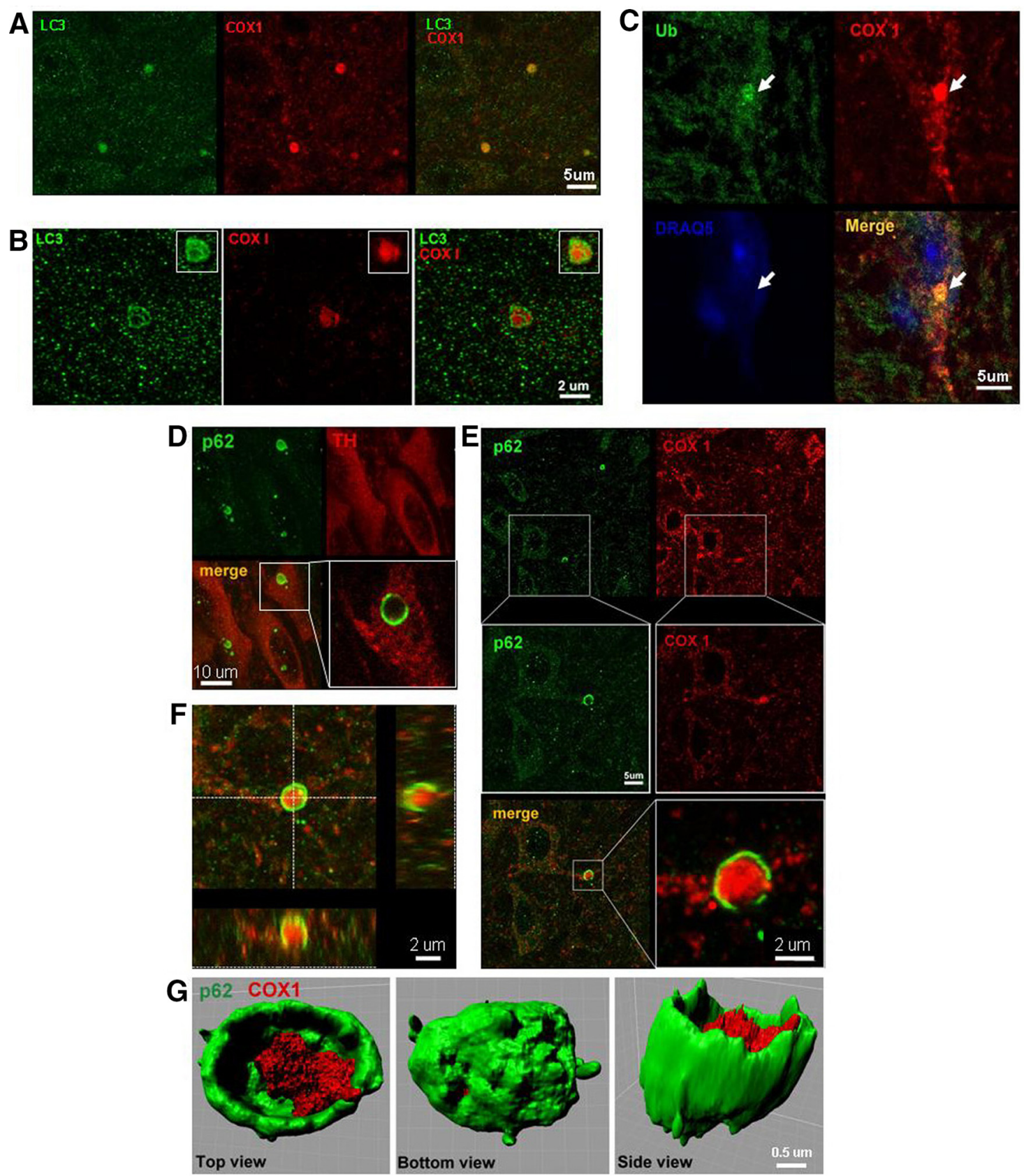

Figure 7. Mitochondrial inclusions were colocalized with macroautophagy markers. A, LC3 had a diffused staining pattern in neurons. Most mitochondrial inclusions (red, COX1), but not surrounding mitochondria, were strongly colocalized with LC3. B, In some mitochondrial inclusions, LC3-positive membrane-like structures encapsulated mitochondrial inclusions. The brightness of red channel (COX1) was adjusted to avoid red channel clipping when acquiring images. As a result, the surrounding mitochondria had very low staining signal because of their weaker COX1 staining intensity than mitochondrial inclusions. The images were deconvoluted with LAS AF software (Leica). Insets, top right, Raw images without deconvolution. C, Most mitochondrial inclusions (red, COX1) were also stained weakly for ubiquitin (green, Ub). DRAQ5 was used to identify nucleus and soma. $\boldsymbol{D}$, Double fluorescence staining identified p62-positive ring-like structures (green) within cytoplasm of DA neurons (TH, red) of DA $A_{\text {sys53 }}$ mice. Such p62 structures were found in neither other cells nor in control mice. The p62-positive rings were $0.5-2 \mu \mathrm{m}$ in diameter, similar to mitochondrial inclusions. The rim thickness of the rings varied slightly $(275.7 \pm 12.9 \mathrm{~nm})$. Bottom right, Magnified view of one p62 ring. E, Double fluorescence staining revealed that mitochondrial inclusions (red, COX1) were the major content inside p62 rings. Top, Two such rings at lower magnification. One was magnified to show colocalization of p62 ring and a mitochondrial inclusion. All p62-positive rings encased mitochondrial inclusions (24 of 24 p62 rings examined). $\boldsymbol{F}$, Confocal orthogonal sectioning confirmed that mitochondrial inclusions (red, C0X1) were encased within p62-positive rings (green, p62). G, Three-dimensional reconstruction revealed that such p62 structures form shells incompletely encapsulating mitochondrial inclusion.

lead to overt mitochondrial pathology (Palacino et al., 2004; Devi et al., 2008; Gautier et al., 2008), leading to the hypothesis that parkin/PINK1-dependent mitophagy may not be essential in the brain and in DA neurons under nonstressed conditions (Youle and Narendra, 2011) or parkin/PINK1-independent mitophagy may be at play (Allen et al., 2013; Fu et al., 2013).

In light of the mitochondria-specific macroautophagy observed in the $\mathrm{DA}_{\mathrm{SYN} 53}$ mice, we next examined whether parkin or PINK1 is required under these conditions. We first generated a triple-transgenic mouse line by breeding $\mathrm{DA}_{\mathrm{SYN} 53}$ double-transgenic mice onto the parkin null background $\left(\mathrm{DA}_{\mathrm{SYN} 53} \mathrm{PRK}^{\text {null }}\right)$. Genetic deletion of parkin in control mice alone did not reveal obvious mitochondria morphological defects, similar to what has been reported previously (Palacino et al., 2004). However, genetic deletion of parkin in $\mathrm{DA}_{\mathrm{SYN} 53}$ mice significantly enlarged mitochondrial inclusions (Fig. 9A,B) 
(4.4 $\pm 0.6 \mu \mathrm{m}$ in triple-transgenic vs $0.8 \pm 0.2 \mu \mathrm{m}$ in double-transgenic, $p<$ $0.0001, n=20$ neurons from 3 mice) and reduced mitochondria mass $(57 \%$ reduction, $p<0.001, n=20$ neurons from 3 mice) in DA neurons at 3 weeks. The number of mitochondrial inclusions did not change significantly $(1.7 \pm 0.2$ mitochondrial inclusions/DA neuron vs $1.6 \pm$ 0.3 mitochondrial inclusions/DA neuron, $n=20$ neurons from 3 mice) (Fig. $9 A, C$ ). Next, using the same breeding scheme as above, $\mathrm{DA}_{\mathrm{SYN} 53} \mathrm{PINK}^{\text {null }}$ mice were generated. $\mathrm{DA}_{\mathrm{SYN} 53} \mathrm{PINK}^{\text {null }}$ mice, compared with $\mathrm{DA}_{\mathrm{SYN} 53}$ mice, developed significantly enlarged mitochondrial inclusions $(4.2 \pm 0.5 \mu \mathrm{m}$ vs $0.8 \pm 0.2 \mu \mathrm{m}, p<$ $0.0001, n=20$ neurons from 3 mice) and reduced mitochondria mass $(51 \%$ reduction, $p<0.001, n=20$ neurons from 3 mice) with unchanged mitochondrial inclusion number $(1.4 \pm 0.5$ mitochondrial inclusions /DA neuron vs $1.6 \pm 0.3$ mitochondrial inclusions/DA neuron, $n=20$ neurons from 3 mice) in DA neurons at 3 weeks, virtually indistinguishable from $\mathrm{DA}_{\mathrm{SYN} 53} \mathrm{PRK}^{\text {null }}$ mice (Fig. 9A,C). Genetic deletion of PINK1 alone did not reveal obvious mitochondria morphological defects as expected (Devi et al., 2008; Gautier et al., 2008). In both $\mathrm{DA}_{\mathrm{SYN} 53} \mathrm{PRK}^{\text {null }}$ and $\mathrm{DA}_{\mathrm{SYN} 53} \mathrm{PINK}^{\text {null }}$ mice, similar to $\mathrm{DA}_{\mathrm{SYN} 53}$ mice, the mitochondrial inclusions remained LC3-, p62-, and ubiquitin-positive (Fig. 9D) but negative for Golgi and ER markers (Fig. 9E).

To assess whether worsened mitochondria abnormalities are accompanied with accelerated DA neuron loss in both $\mathrm{DA}_{\mathrm{SYN} 53} \mathrm{PRK}^{\text {null }}$ and $\mathrm{DA}_{\mathrm{SYN} 53} \mathrm{PINK}^{\text {null }}$ mice at 3 weeks, stereological counting of DA neurons was performed ( $n=5$ mice). There was no evidence of accelerated DA neuron loss in $\mathrm{DA}_{\mathrm{SYN} 53} \mathrm{PRK}^{\text {null }}$ and $\mathrm{DA}_{\mathrm{SYN} 53} \mathrm{PINK}{ }^{\text {null }}$ mice compared with $\mathrm{DA}_{\text {SYN53 }}$ mice at this age (Fig. 9C). At this point, there was still no proof for a causal link between mitochondria abnormalities and DA neuron loss in this transgenic mouse study.

\section{Discussion}

Postnatal overexpression of $\alpha$-synuclein induced DA neuron loss with three clearly defined stages of pathology progression

$\alpha$-Synuclein is a major component of Lewy bodies, the characteristic cellular inclusions in PD and other Lewy body diseases (Spillantini et al., 1997). Genome-wide association studies support SNCA ( $\alpha$-synuclein) as one of few confirmed risk factors for sporadic PD (Gandhi and Wood, 2010). During normal aging, $\alpha$-synuclein level gradually increases in DA neurons in humans (Chu and Kordower, 2007). Missense muta-
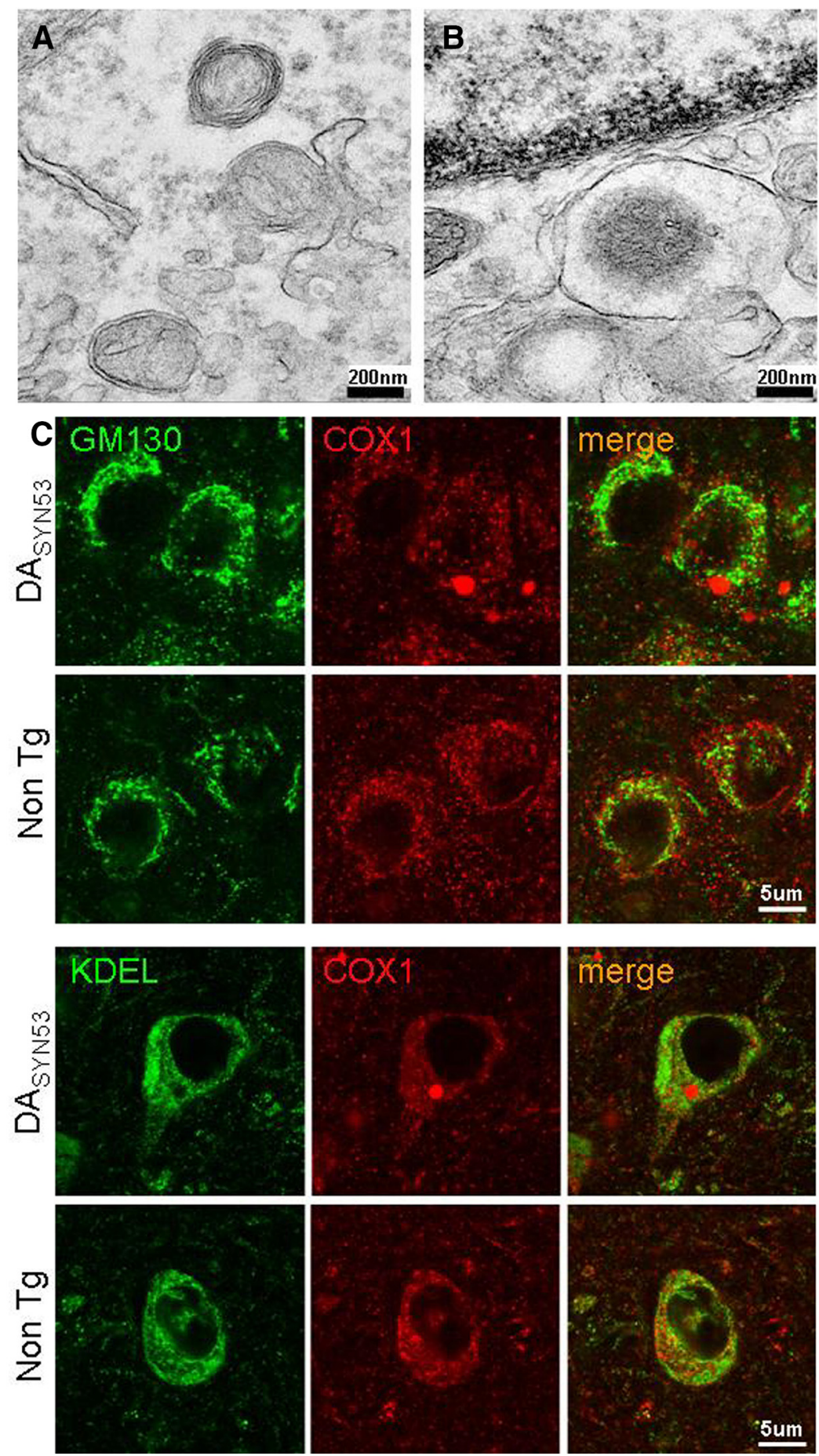

Figure 8. $\quad \alpha$-Synuclein induced mitochondria-specific macroautophagy without triggering bulk macroautophagy. $A$, At the EM level, senescent mitochondria appeared being engulfed by double-membrane-like structures. $\boldsymbol{B}$, A senescent mitochondrion was completely engulfed by a double-membrane-like structure. C, Double immunofluorescent staining for a Golgi marker (GM130) and mitochondria marker (COX I) revealed that there was neither colocalization of mitochondrial inclusions with Golgi nor obvious morphological abnormalities of Golgi. Similarly, a ER marker (KDEL) revealed neither colocalization of mitochondrial inclusions with ER nor obvious morphological abnormalities of ER.

tions, including A53T mutant, and duplication/triplication of $\alpha$-synuclein have been causally linked to familial PD (Polymeropoulos et al., 1997; Singleton et al., 2003; Chartier-Harlin et al., 2004).

To model dominant inheritance neurodegenerative diseases, it is often necessary to overexpress the gain-of-function mutant genes. For PD, although transgenic mice with $\alpha$-synuclein overexpression in non-DA neurons have been well documented 

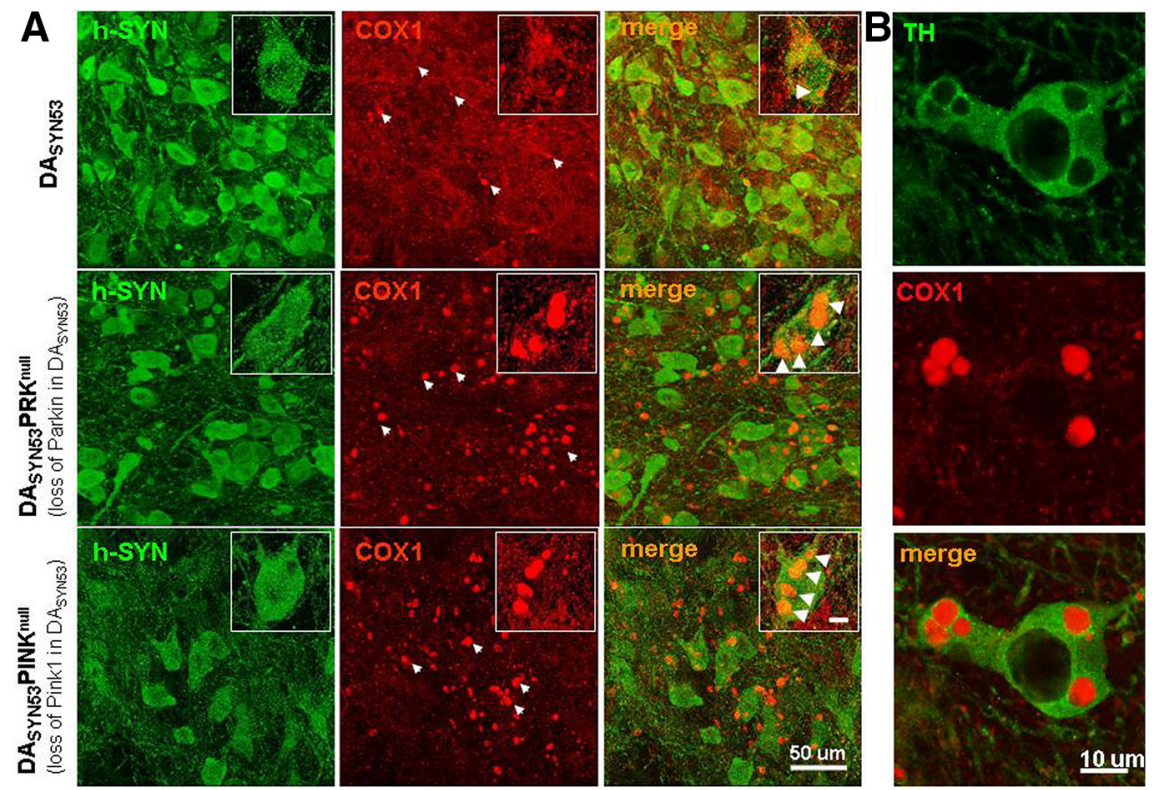

C
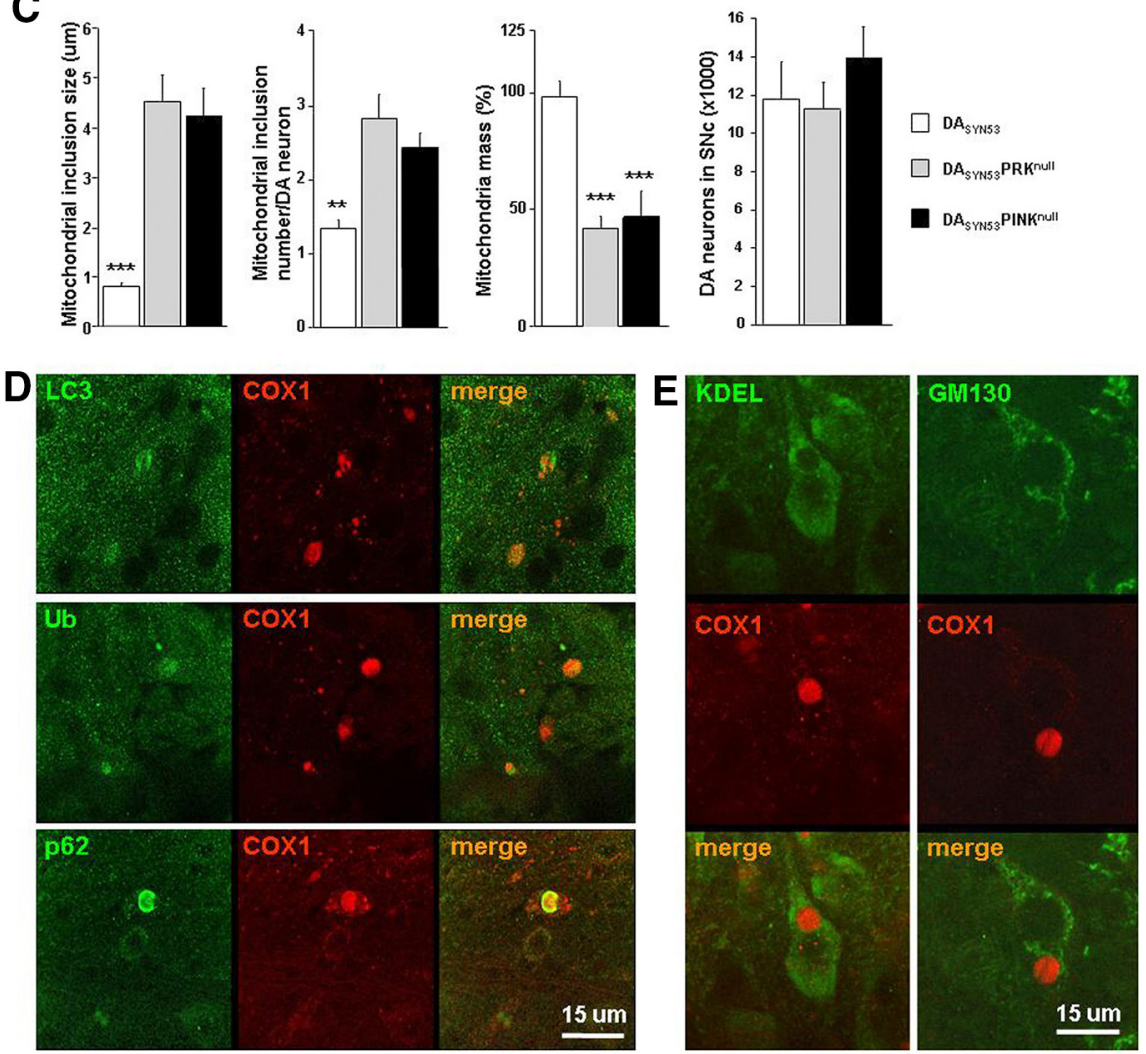

Figure 9. Loss of parkin or PINK1 significantly worsened mitochondria abnormalities in DA neurons. $\boldsymbol{A}$, At 3 weeks, both $D_{\text {SYN53 }}$ PRK $^{\text {null }}$ and DA ${ }_{\text {SYN53 }}$ PINK $^{\text {null }}$ mice had significantly enlarged $(4-6 \mu \mathrm{m})$ mitochondrial inclusions and reduced mitochondria in DA neurons in contrast to $\mathrm{DA}_{\mathrm{SYN} 53}$ mice $(n=3$ mice). The quantifications were shown in $\boldsymbol{C}$. Inset, Higher-magnification images of neurons to show mitochondrial inclusions (arrowhead) and mitochondria mass. Scale bar, $5 \mu \mathrm{m}$. $\boldsymbol{B}$, A representative DA neuron in $\mathrm{DA}_{\mathrm{SYN53}} \mathrm{PRK}^{\text {null }}$ mice containing several enlarged mitochondrial inclusions. The same results were obtained in $\mathrm{DA}_{\mathrm{SYN} 53}{ }_{\mathrm{PINK}}{ }^{\text {null }}$ mice (data not shown). C, Quantification of mitochondrial inclusion size, number, mitochondria mass in DA neurons, and DA neuron number in SNc at 3 weeks. Compared with $\mathrm{DA}_{\mathrm{SYN53}}$ mice, the average size of mitochondrial inclusions and mitochondria mass in $D_{\text {SYN53 }}$ PRK $^{\text {null }}$ and $D A_{\text {SYN53 }}{ }$ INKK $^{\text {null }}$ mice was significantly increased and decreased, respectively, while the number of mitochondrial inclusions and the number of DA neurons were unchanged. ${ }^{* *} p<0.01$. ${ }^{* * *} p<0.001$. D, Representative pictures show that mitochondrial inclusions in $D_{\text {SYN53 }} P R K^{\text {null }}$ remained $L C 3$, p62, ubiquitin-positive, similar to $D A_{S Y N 53}$ mice. The same results were obtained in $D_{\text {SYN53 }} P_{I N K}{ }^{\text {null }}$ mice (data not shown). $\boldsymbol{E}$, Representative pictures show that neither Golgi nor ER was affected as revealed by the Golgi marker GM130 and ER marker KDEL in DA ${ }_{S Y N 53}$ PRK $^{\text {null }}$ mice. The same results were obtained in $\mathrm{DA}_{\mathrm{SYN} 53}$ PINK $^{\text {null }}$ mice (data not shown).
(Dawson et al., 2010), the challenge is to achieve overexpression in DA neurons. We have designed a novel cell typespecific "PF" transgene expression amplification strategy to overexpress the human $\alpha$-synuclein A53T (SYN) specifically in DA neurons.

Our genetic approach achieved eightfold overexpression of transgenic $\alpha$-synuclein in DA neurons compared with endogenous mouse $\alpha$-synuclein level, which leads to three clearly defined stages of pathology progression: Stage 1: at 3 weeks, DA neurons had widespread mitochondria defects and formation of abundant mitochondrial inclusions. At this stage, no other morphological changes or degeneration of DA neurons were obvious. Stage 2: at 6 weeks, DA neurons had severe morphological abnormalities of DA neuron axons and dendrites with fewer mitochondrial inclusions. At this stage, no DA neuron death was observed. Stage 3: at 3 months, DA neuron degeneration was obvious $(21 \%)$ and accompanied with severe DA axonal terminal loss. The loss of DA neuron reached $\sim 35 \%$ at 6 months. The observation that mitochondrial inclusions are the earliest DA neuron pathology and its gradual decline as DA neuron degeneration worsens suggests that mitochondria and mitophagy impairments might be the cause rather than consequence of neurodegeneration in the $\mathrm{DA}_{\mathrm{SYN} 53}$ mice.

\section{Mitochondria might be major targets of $\boldsymbol{\alpha}$-synuclein}

Despite previously reported broad effects of $\alpha$-synuclein on multiple subcellular organelles, our present data point to mitochondria as the major targets of $\alpha$-synuclein, which is in agreement with some in vitro studies. It has been reported that $\alpha$-synuclein harbors cryptic mitochondria targeting signal on its $\mathrm{N}$ terminus (Devi et al., 2008; Nakamura et al., 2008). Moreover, $\alpha$-synuclein has an affinity for mitochondria-specific cardiolipin (Nakamura et al., 2008). It has also been reported that $\alpha$-synuclein is a membrane curvature sensor that has a preference for membranes with high curvature, such as mitochondria inner membrane and synaptic vesicles (Jensen et al., 2011).

Both our immunofluorescence and immuno-EM data support the physical localization of human $\alpha$-synuclein within mitochondria in DA neurons of the $\mathrm{DA}_{\mathrm{SYN} 53}$ mice. Even though the physiological significance of mitochondrial membrane binding of $\alpha$-synuclein is still unknown, it is likely that, under normal conditions, it does not have much adverse impact on mitochondria functions 
(Nakamura et al., 2011). However, functional disturbance of mitochondria by $\alpha$-synuclein may emerge during aging or under pathological conditions. During normal aging, $\alpha$-synuclein level gradually increases in DA neurons in humans (Chu and Kordower, 2007). In PD patients carrying $\alpha$-synuclein gene multiplication mutations (Singleton et al., 2003; Chartier-Harlin et al., 2004), the overexpressed $\alpha$-synuclein may increase its mitochondria localization and functional disturbance (Bendor et al., 2013), such as in our mouse model. It has been reported that mitochondria membrane-bound $\alpha$-synuclein indeed increases dramatically in PD (Devi et al., 2008). Conversely, $\alpha$-synuclein knock-out mice have lower mitochondrial lipid cardiolipin (Ellis et al., 2005) and are relatively resistant to the mitochondrial inhibitor MPTP-induced nigrostriatal DA neuron lesion (Dauer et al., 2002; Drolet et al., 2004; Fornai et al., 2005).

$\alpha$-Synuclein induces mitochondria-specific macroautophagy In the $\mathrm{DA}_{\mathrm{SYN} 53}$ mice, DA neurons exhibit mitochondria fragmentation and prominent intracellular mitochondrial inclusions. However, the total mitochondria content is normal, and neither EM nor fluorescence microscopy identified nonselective macroautophagic removal of ER or Golgi. The expression level of p62, which usually partially reflects general autophagy activity, is not significantly changed in DA neurons of $\mathrm{DA}_{\mathrm{SYN} 53}$ mice. Therefore, our data suggest that mitophagy is mobilized to specifically remove $\alpha$-synuclein-damaged mitochondria without affecting general bulk macroautophagy.

Our data further suggest that the mitophagy may contribute to intracellular mitochondrial inclusion formation in the $\mathrm{DA}_{\mathrm{SYN} 53}$ mice, which is substantially different from the mitochondrial inclusions reported previously in other PD models. In the MitoPark mice, mitochondrial inclusions are essentially abnormally enlarged mitochondria (Ekstrand et al., 2007). More importantly, parkin deficiency does not alter the enlarged mitochondria in MitoPark mice (Sterky et al., 2011), indicating that parkin does not participate in removing some types of mitochondria damage. In a cybrid cell line harboring defective mitochondria derived from PD patients, Lewy body-like inclusions were observed (Trimmer et al., 2004). However, their ultrastructure morphologies are different from mitochondrial inclusions observed in the present study, suggesting distinct mechanisms of inclusion formation in different experimental settings. Some published studies indicate mitochondria as a possible component in the early stage of Lewy body formation (Roy and Wolman, 1969; Hayashida et al., 1993; Gai et al., 2000; Shults, 2006). However, in the age groups that we studied so far, we did not observe typical Lewy body-like inclusions in our model.

\section{Role of PINK1-parkin pathway in mitophagy and PD}

The nearly identical phenotypes of parkin and PINK1 deficiency in the $\mathrm{DA}_{\mathrm{SYN} 53}$ mice support that parkin and PINK1 function in the same mitochondria quality control pathway, and both are critical in maintaining mitochondria homeostasis under pathological conditions of $\alpha$-synuclein induced mitochondria impairment.

The significant loss of total mitochondria mass in the two triple-transgenic mice suggests that parkin/PINK1-independent mitophagy in these mice might be less selective for damaged mitochondria, indicating that parkin/PINK1-dependent mitophagy could be at least partially responsible for selectively degrading $\alpha$-synuclein-damaged mitochondria in DA neurons and thus be crucial for maintaining mitochondria homeostasis. This possibility is in agreement with the prevailing hypothesis that PINK1 and parkin function in the same mitophagy pathway to selectively remove damaged mitochondria (Youle and Narendra, 2011). However, parkin and PINK1 are not indispensable for mitophagy, which is supported by autophagy marker-positive mitochondrial inclusions in our triple-transgenic mice. Parkin/ PINK1-independent mitophagy mechanisms in DA neurons in our model may exist, which is consistent with some previous findings (Allen et al., 2013; Fu et al., 2013).

In addition to the possible role of parkin/PINK1 in selective mitophagy in our mice, other functions of parkin/PINK1 in maintaining mitochondria homeostasis could not be excluded. It has been reported that parkin regulates the degradation of PARIS and PGC- $1 \alpha$-dependent mitochondrial biogenesis (Shin et al., 2011), which could partially explains the loss of total mitochondria mass in the two triple-transgenic mice.

\section{Comparing our model with other models}

A number of transgenic or viral rodent PD models with wild-type or mutant $\alpha$-synuclein overexpression have been reported (Masliah et al., 2000; Giasson et al., 2002; Kirik et al., 2002; Daher et al., 2009; Dawson et al., 2010; Kuo et al., 2010; Chesselet and Richter, 2011; Prasad et al., 2011; Lin et al., 2012). They have elegantly recapitulated some aspects of synucleinopathy diseases, including PD. DA neuron pathologies in these transgenic models are very mild even at the oldest age, which is likely due to the relatively low transgenic $\alpha$-synuclein expression in DA neurons. Nevertheless, DA neuron degeneration is observed in viral human $\alpha$-synuclein rodent models with higher $\alpha$-synuclein overexpression (Kirik et al., 2002; Kahle, 2008).

In another DA neuron-specific transgenic mouse model, human $\alpha$-synuclein A53T overexpression was achieved using a pitx3-tTA driver line (Lin et al., 2012). The pitx3-synuclein model and the $\mathrm{DA}_{\mathrm{SYN} 53}$ model reported here are the only two transgenic models with strong mutant $\alpha$-synuclein expression in DA neurons and both recapitulate important aspects of PD. In the pitx3-synuclein model, transgenic $\alpha$-synuclein was expressed onefold over endogenous $\alpha$-synuclein in DA neurons and transgenic mice showed DA neuron loss (Lin et al., 2012). Interestingly, the pitx3-synuclein mice display severe locomotion impairment as early as 1 month when DA neuron loss is $10 \%$. This is in contrast to our model that does not show obvious motor symptoms with 40\% DA neuron loss. Moreover, no mitochondria and mitophagy defects were observed in the Pitx3-tTAbased model. In addition, another important difference between these two models is that transgenic $\alpha$-synuclein overexpression takes place postnatally in our model, whereas it starts during embryonic development in the Pitx3-tTA-based model. Even though it is not entirely clear whether higher transgenic $\alpha$-synuclein expression and avoiding embryonic stage overexpression are essential for the specific pathologies in the $\mathrm{DA}_{\mathrm{SYN} 53}$ model, the advantages of these two factors were speculated by others (Dawson et al., 2010).

Although the $\mathrm{DA}_{\mathrm{SYN} 53}$ model has many advantages and unique features, $\mathrm{PD}$ is complex and heterogeneous. No single animal model could recapitulate all aspects of PD. For the present study, there are a number of unanswered questions. (1) The $\mathrm{DA}_{\mathrm{SYN53}}$ mice appear to have normal motor functions. Will they eventually develop PD motor symptoms when they lose more DA neurons? (2) Most of the DA neuron loss occurs before 3 months but then significantly slows down or stops. Will there be more DA neuron loss as mice age? Is this due to selective vulnerability of a subset of DA neurons? (3) Although mitochondria pathology precedes DA neuron loss in $\mathrm{DA}_{\mathrm{SYN} 53}$ mice, the model does not provide causal evidence. In addition, there was no evidence of accelerated DA 
neuron loss in $\mathrm{DA}_{\mathrm{SYN} 53} \mathrm{PRK}^{\text {null }}$ and $\mathrm{DA}_{\mathrm{SYN}}{ }_{3} \mathrm{PINK}^{\text {null }}$ mice compared with $\mathrm{DA}_{\mathrm{SYN} 53}$ mice in the age group that we studied (Fig. 9 C). Will there be worsened DA neuron loss due to parkin or PINK1 deficiency as mice age? All these questions will have to be addressed in the future. They may represent the limitations of the $\mathrm{DA}_{\text {SYN53 }}$ model, or they might lead to surprising new insights.

In conclusion, here we report, to our knowledge, the first evidence of obvious mitochondria-specific macroautophagy in DA neurons in vivo and, importantly, it is induced by $\alpha$-synuclein and precedes DA neuron degeneration. Moreover, our data demonstrated, for the first time, a synergy between $\alpha$-synuclein pathology and parkin or PINK1 deficiency in causing mitochondria impairments in an in vivo model, supporting that proper mitochondria quality control is vital for DA neuron survival.

\section{References}

Allen GF, Toth R, James J, Ganley IG (2013) Loss of iron triggers PINK1/ Parkin-independent mitophagy. EMBO Rep 14:1127-1135. CrossRef Medline

Ashrafi G, Schwarz TL (2013) The pathways of mitophagy for quality control and clearance of mitochondria. Cell Death Differ 20:31-42. CrossRef Medline

Baloh RH, Salavaggione E, Milbrandt J, Pestronk A (2007) Familial parkinsonism and ophthalmoplegia from a mutation in the mitochondrial DNA helicase twinkle. Arch Neurol 64:998-1000. CrossRef Medline

Bender A, Krishnan KJ, Morris CM, Taylor GA, Reeve AK, Perry RH, Jaros E, Hersheson JS, Betts J, Klopstock T, Taylor RW, Turnbull DM (2006) High levels of mitochondrial DNA deletions in substantia nigra neurons in aging and Parkinson disease. Nat Genet 38:515-517. CrossRef Medline

Bendor JT, Logan TP, Edwards RH (2013) The function of alpha-synuclein. Neuron 79:1044-1066. CrossRef Medline

Cagniard B, Beeler JA, Britt JP, McGehee DS, Marinelli M, Zhuang X (2006) Dopamine scales performance in the absence of new learning. Neuron 51:541-547. CrossRef Medline

Cai Q, Zakaria HM, Simone A, Sheng ZH (2012) Spatial parkin translocation and degradation of damaged mitochondria via mitophagy in live cortical neurons. Curr Biol 22:545-552. CrossRef Medline

Chartier-Harlin MC, Kachergus J, Roumier C, Mouroux V, Douay X, Lincoln S, Levecque C, Larvor L, Andrieux J, Hulihan M, Waucquier N, Defebvre L, Amouyel P, Farrer M, Destée A (2004) Alpha-synuclein locus duplication as a cause of familial Parkinson's disease. Lancet 364:1167-1169. CrossRef Medline

Chen J, Kelz MB, Zeng G, Sakai N, Steffen C, Shockett PE, Picciotto MR, Duman RS, Nestler EJ (1998) Transgenic animals with inducible, targeted gene expression in brain. Mol Pharmacol 54:495-503. CrossRef Medline

Chen L, Cagniard B, Mathews T, Jones S, Koh HC, Ding Y, Carvey PM, Ling Z, Kang UJ, Zhuang X (2005) Age-dependent motor deficits and dopaminergic dysfunction in DJ-1 null mice. J Biol Chem 280:21418-21426. CrossRef Medline

Chesselet MF (2008) In vivo alpha-synuclein overexpression in rodents: a useful model of Parkinson's disease? Exp Neurol 209:22-27. CrossRef Medline

Chesselet MF, Richter F (2011) Modelling of Parkinson's disease in mice. Lancet Neurol 10:1108-1118. CrossRef Medline

Chinta SJ, Mallajosyula JK, Rane A, Andersen JK (2010) Mitochondrial alpha-synuclein accumulation impairs complex I function in dopaminergic neurons and results in increased mitophagy in vivo. Neurosci Lett 486:235-239. CrossRef Medline

Choubey V, Safiulina D, Vaarmann A, Cagalinec M, Wareski P, Kuum M, Zharkovsky A, Kaasik A (2011) Mutant A53T alpha-synuclein induces neuronal death by increasing mitochondrial autophagy. J Biol Chem 286: 10814-10824. CrossRef Medline

Chu Y, Kordower JH (2007) Age-associated increases of alpha-synuclein in monkeys and humans are associated with nigrostriatal dopamine depletion: is this the target for Parkinson's disease? Neurobiol Dis 25:134-149. CrossRef Medline

Clark IE, Dodson MW, Jiang C, Cao JH, Huh JR, Seol JH, Yoo SJ, Hay BA, Guo M (2006) Drosophila pink1 is required for mitochondrial function and interacts genetically with parkin. Nature 441:1162-1166. CrossRef Medline

Colla E, Jensen PH, Pletnikova O, Troncoso JC, Glabe C, Lee MK (2012) Accumulation of toxic alpha-synuclein oligomer within endoplasmic reticulum occurs in alpha-synucleinopathy in vivo. J Neurosci 32:33013305. CrossRef Medline

Cooper AA, Gitler AD, Cashikar A, Haynes CM, Hill KJ, Bhullar B, Liu K, Xu K, Strathearn KE, Liu F, Cao S, Caldwell KA, Caldwell GA, Marsischky G, Kolodner RD, Labaer J, Rochet JC, Bonini NM, Lindquist S (2006) $\alpha$-Synuclein blocks ER-Golgi traffic and Rab1 rescues neuron loss in Parkinson's models. Science 313:324-328. CrossRef Medline

Daher JP, Ying M, Banerjee R, McDonald RS, Hahn MD, Yang L, Flint Beal M, Thomas B, Dawson VL, Dawson TM, Moore DJ (2009) Conditional transgenic mice expressing C-terminally truncated human alpha-synuclein (alphaSyn119) exhibit reduced striatal dopamine without loss of nigrostriatal pathway dopaminergic neurons. Mol Neurodegener 4:34. CrossRef Medline

Dauer W, Przedborski S (2003) Parkinson's disease: mechanisms and models. Neuron 39:889-909. CrossRef Medline

Dauer W, Kholodilov N, Vila M, Trillat AC, Goodchild R, Larsen KE, Staal R, Tieu K, Schmitz Y, Yuan CA, Rocha M, Jackson-Lewis V, Hersch S, Sulzer D, Przedborski S, Burke R, Hen R (2002) Resistance of alpha-synuclein null mice to the parkinsonian neurotoxin MPTP. Proc Natl Acad Sci U S A 99:14524-14529. CrossRef Medline

Dawson TM, Ko HS, Dawson VL (2010) Genetic animal models of Parkinson's disease. Neuron 66:646-661. CrossRef Medline

Devi L, Raghavendran V, Prabhu BM, Avadhani NG, Anandatheerthavarada HK (2008) Mitochondrial import and accumulation of alpha-synuclein impair complex I in human dopaminergic neuronal cultures and Parkinson disease brain. J Biol Chem 283:9089-9100. CrossRef Medline

de Vries RL, Przedborski S (2013) Mitophagy and Parkinson's disease: be eaten to stay healthy. Mol Cell Neurosci 55:37-43. CrossRef Medline

Drolet RE, Behrouz B, Lookingland KJ, Goudreau JL (2004) Mice lacking alpha-synuclein have an attenuated loss of striatal dopamine following prolonged chronic MPTP administration. Neurotoxicology 25:761-769. CrossRef Medline

Ekstrand MI, Terzioglu M, Galter D, Zhu S, Hofstetter C, Lindqvist E, Thams S, Bergstrand A, Hansson FS, Trifunovic A, Hoffer B, Cullheim S, Mohammed AH, Olson L, Larsson NG (2007) Progressive parkinsonism in mice with respiratory-chain-deficient dopamine neurons. Proc Natl Acad Sci U S A 104:1325-1330. CrossRef Medline

Ellis CE, Murphy EJ, Mitchell DC, Golovko MY, Scaglia F, Barceló-Coblijn GC, Nussbaum RL (2005) Mitochondrial lipid abnormality and electron transport chain impairment in mice lacking alpha-synuclein. Mol Cell Biol 25:10190-10201. CrossRef Medline

Fornai F, Schlüter OM, Lenzi P, Gesi M, Ruffoli R, Ferrucci M, Lazzeri G, Busceti CL, Pontarelli F, Battaglia G, Pellegrini A, Nicoletti F, Ruggieri S, Paparelli A, Südhof TC (2005) Parkinson-like syndrome induced by continuous MPTP infusion: convergent roles of the ubiquitinproteasome system and alpha-synuclein. Proc Natl Acad Sci U S A 102: 3413-3418. CrossRef Medline

Fu M, St-Pierre P, Shankar J, Wang PT, Joshi B, Nabi IR (2013) Regulation of mitophagy by the Gp78 E3 ubiquitin ligase. Mol Biol Cell 24:11531162. CrossRef Medline

Gai WP, Yuan HX, Li XQ, Power JT, Blumbergs PC, Jensen PH (2000) In situ and in vitro study of colocalization and segregation of alphasynuclein, ubiquitin, and lipids in Lewy bodies. Exp Neurol 166:324-333. CrossRef Medline

Gandhi S, Wood NW (2010) Genome-wide association studies: the key to unlocking neurodegeneration? Nat Neurosci 13:789-794. CrossRef Medline

Gautier CA, Kitada T, Shen J (2008) Loss of PINK1 causes mitochondrial functional defects and increased sensitivity to oxidative stress. Proc Natl Acad Sci U S A 105:11364-11369. CrossRef Medline

Geisler S, Holmström KM, Skujat D, Fiesel FC, Rothfuss OC, Kahle PJ, Springer W (2010) PINK1/Parkin-mediated mitophagy is dependent on VDAC1 and p62/SQSTM1. Nat Cell Biol 12:119-131. CrossRef Medline

Giasson BI, Duda JE, Quinn SM, Zhang B, Trojanowski JQ, Lee VM (2002) Neuronal alpha-synucleinopathy with severe movement disorder in mice expressing A53T human alpha-synuclein. Neuron 34:521-533. CrossRef Medline

Goldberg MS, Fleming SM, Palacino JJ, Cepeda C, Lam HA, Bhatnagar A, 
Meloni EG, Wu N, Ackerson LC, Klapstein GJ, Gajendiran M, Roth BL, Chesselet MF, Maidment NT, Levine MS, Shen J (2003) Parkindeficient mice exhibit nigrostriatal deficits but not loss of dopaminergic neurons. J Biol Chem 278:43628-43635. CrossRef Medline

Götz J, Tolnay M, Barmettler R, Chen F, Probst A, Nitsch RM (2001) Oligodendroglial tau filament formation in transgenic mice expressing G272V tau. Eur J Neurosci 13:2131-2140. CrossRef Medline

Grenier K, McLelland GL, Fon EA (2013) Parkin- and PINK1-dependent mitophagy in neurons: will the real pathway please stand up? Front Neurol 4:100. CrossRef Medline

Guardia-Laguarta C, Area-Gomez E, Rüb C, Liu Y, Magrané J, Becker D, Voos W, Schon EA, Przedborski S (2014) alpha-Synuclein is localized to mitochondria-associated ER membranes. J Neurosci 34:249-259. CrossRef Medline

Hayashida K, Oyanagi S, Mizutani Y, Yokochi M (1993) An early cytoplasmic change before Lewy body maturation: an ultrastructural study of the substantia nigra from an autopsy case of juvenile parkinsonism. Acta Neuropathol 85:445-448. CrossRef Medline

Jensen MB, Bhatia VK, Jao CC, Rasmussen JE, Pedersen SL, Jensen KJ, Langen R, Stamou D (2011) Membrane curvature sensing by amphipathic helices: a single liposome study using alpha-synuclein and annexin B12. J Biol Chem 286:42603-42614. CrossRef Medline

Johansen T, Lamark T (2011) Selective autophagy mediated by autophagic adapter proteins. Autophagy 7:279-296. CrossRef Medline

Kahle PJ (2008) alpha-Synucleinopathy models and human neuropathology: similarities and differences. Acta Neuropathol 115:87-95. CrossRef Medline

Kamp F, Exner N, Lutz AK, Wender N, Hegermann J, Brunner B, Nuscher B, Bartels T, Giese A, Beyer K, Eimer S, Winklhofer KF, Haass C (2010) Inhibition of mitochondrial fusion by alpha-synuclein is rescued by PINK1, Parkin and DJ-1. EMBO J 29:3571-3589. CrossRef Medline

Keeney PM, Xie J, Capaldi RA, Bennett JP Jr (2006) Parkinson's disease brain mitochondrial complex I has oxidatively damaged subunits and is functionally impaired and misassembled. J Neurosci 26:5256-5264. CrossRef Medline

Kirik D, Rosenblad C, Burger C, Lundberg C, Johansen TE, Muzyczka N, Mandel RJ, Björklund A (2002) Parkinson-like neurodegeneration induced by targeted overexpression of alpha-synuclein in the nigrostriatal system. J Neurosci 22:2780-2791. Medline

Klionsky DJ, Abdalla FC, Abeliovich H, Abraham RT, Acevedo-Arozena A, Adeli K, Agholme L, Agnello M, Agostinis P, Aguirre-Ghiso JA, Ahn HJ, Ait-Mohamed O, Ait-Si-Ali S, Akematsu T, Akira S, Al-Younes HM, AlZeer MA, Albert ML, Albin RL, Alegre-Abarrategui J, et al. (2012) Guidelines for the use and interpretation of assays for monitoring autophagy. Autophagy 8:445-544. CrossRef Medline

Kuo YM, Li Z, Jiao Y, Gaborit N, Pani AK, Orrison BM, Bruneau BG, Giasson BI, Smeyne RJ, Gershon MD, Nussbaum RL (2010) Extensive enteric nervous system abnormalities in mice transgenic for artificial chromosomes containing Parkinson disease-associated alpha-synuclein gene mutations precede central nervous system changes. Hum Mol Genet 19: 1633-1650. CrossRef Medline

Langston JW, Ballard P, Tetrud JW, Irwin I (1983) Chronic Parkinsonism in humans due to a product of meperidine-analog synthesis. Science 219: 979-980. CrossRef Medline

Lee VM, Trojanowski JQ (2006) Mechanisms of Parkinson's disease linked to pathological alpha-synuclein: new targets for drug discovery. Neuron 52:33-38. CrossRef Medline

Lin X, Parisiadou L, Gu XL, Wang L, Shim H, Sun L, Xie C, Long CX, Yang WJ, Ding J, Chen ZZ, Gallant PE, Tao-Cheng JH, Rudow G, Troncoso JC, Liu Z, Li Z, Cai H (2009) Leucine-rich repeat kinase 2 regulates the progression of neuropathology induced by Parkinson's-disease-related mutant alpha-synuclein. Neuron 64:807-827. CrossRef Medline

Lin X, Parisiadou L, Sgobio C, Liu G, Yu J, Sun L, Shim H, Gu XL, Luo J, Long CX, Ding J, Mateo Y, Sullivan PH, Wu LG, Goldstein DS, Lovinger D, Cai H (2012) Conditional expression of Parkinson's disease-related mutant alpha-synuclein in the midbrain dopaminergic neurons causes progressive neurodegeneration and degradation of transcription factor nuclear receptor related 1. J Neurosci 32:9248-9264. CrossRef Medline

Luoma P, Melberg A, Rinne JO, Kaukonen JA, Nupponen NN, Chalmers RM, Oldfors A, Rautakorpi I, Peltonen L, Majamaa K, Somer H, Suomalainen A (2004) Parkinsonism, premature menopause, and mitochondrial
DNA polymerase gamma mutations: clinical and molecular genetic study. Lancet 364:875-882. CrossRef Medline

Martinez-Vicente M, Talloczy Z, Kaushik S, Massey AC, Mazzulli J, Mosharov EV, Hodara R, Fredenburg R, Wu DC, Follenzi A, Dauer W, Przedborski S, Ischiropoulos H, Lansbury PT, Sulzer D, Cuervo AM (2008) Dopaminemodified alpha-synuclein blocks chaperone-mediated autophagy. J Clin Invest 118:777-788. CrossRef Medline

Masliah E, Rockenstein E, Veinbergs I, Mallory M, Hashimoto M, Takeda A, Sagara Y, Sisk A, Mucke L (2000) Dopaminergic loss and inclusion body formation in alpha-synuclein mice: implications for neurodegenerative disorders. Science 287:1265-1269. CrossRef Medline

Mathew R, Karp CM, Beaudoin B, Vuong N, Chen G, Chen HY, Bray K, Reddy A, Bhanot G, Gelinas C, Dipaola RS, Karantza-Wadsworth V, White E (2009) Autophagy suppresses tumorigenesis through elimination of p62. Cell 137:1062-1075. CrossRef Medline

Nakamura K, Nemani VM, Wallender EK, Kaehlcke K, Ott M, Edwards RH (2008) Optical reporters for the conformation of alpha-synuclein reveal a specific interaction with mitochondria. J Neurosci 28:12305-12317. CrossRef Medline

Nakamura K, Nemani VM, Azarbal F, Skibinski G, Levy JM, Egami K, Munishkina L, Zhang J, Gardner B, Wakabayashi J, Sesaki H, Cheng Y, Finkbeiner S, Nussbaum RL, Masliah E, Edwards RH (2011) Direct membrane association drives mitochondrial fission by the Parkinson disease-associated protein alpha-synuclein. J Biol Chem 286:2071020726. CrossRef Medline

Narendra D, Tanaka A, Suen DF, Youle RJ (2008) Parkin is recruited selectively to impaired mitochondria and promotes their autophagy. J Cell Biol 183:795-803. CrossRef Medline

Nezis IP, Stenmark H (2012) p62 at the interface of autophagy, oxidative stress signaling, and cancer. Antioxid Redox Signal 17:786-793. CrossRef Medline

Nunnari J, Suomalainen A (2012) Mitochondria: in sickness and in health. Cell 148:1145-1159. CrossRef Medline

Palacino JJ, Sagi D, Goldberg MS, Krauss S, Motz C, Wacker M, Klose J, Shen J (2004) Mitochondrial dysfunction and oxidative damage in parkindeficient mice. J Biol Chem 279:18614-18622. CrossRef Medline

Park J, Lee SB, Lee S, Kim Y, Song S, Kim S, Bae E, Kim J, Shong M, Kim JM, Chung J (2006) Mitochondrial dysfunction in Drosophila PINK1 mutants is complemented by parkin. Nature 441:1157-1161. CrossRef Medline

Perier C, Vila M (2012) Mitochondrial biology and Parkinson's disease. Cold Spring Harb Perspect Med 2:a009332. CrossRef Medline

Polymeropoulos MH, Lavedan C, Leroy E, Ide SE, Dehejia A, Dutra A, Pike B, Root H, Rubenstein J, Boyer R, Stenroos ES, Chandrasekharappa S, Athanassiadou A, Papapetropoulos T, Johnson WG, Lazzarini AM, Duvoisin RC, Di Iorio G, Golbe LI, Nussbaum RL (1997) Mutation in the alphasynuclein gene identified in families with Parkinson's disease. Science 276:2045-2047. CrossRef Medline

Prasad K, Tarasewicz E, Strickland PA, O’Neill M, Mitchell SN, Merchant K, Tep S, Hilton K, Datwani A, Buttini M, Mueller-Steiner S, Richfield EK (2011) Biochemical and morphological consequences of human alphasynuclein expression in a mouse alpha-synuclein null background. Eur J Neurosci 33:642-656. CrossRef Medline

Rakovic A, Shurkewitsch K, Seibler P, Grünewald A, Zanon A, Hagenah J, Krainc D, Klein C (2013) Phosphatase and tensin homolog (PTEN)induced putative kinase 1 (PINK1)-dependent ubiquitination of endogenous Parkin attenuates mitophagy: study in human primary fibroblasts and induced pluripotent stem cell-derived neurons. J Biol Chem 288: 2223-2237. CrossRef Medline

Roy S, Wolman L (1969) Ultrastructural observations in Parkinsonism. J Pathol 99:39-44. CrossRef Medline

Schapira AH, Cooper JM, Dexter D, Jenner P, Clark JB, Marsden CD (1989) Mitochondrial complex I deficiency in Parkinson's disease. Lancet 1:1269. CrossRef Medline

Schon EA, Przedborski S (2011) Mitochondria: the next (neurode)generation. Neuron 70:1033-1053. CrossRef Medline

Shin JH, Ko HS, Kang H, Lee Y, Lee YI, Pletinkova O, Troconso JC, Dawson VL, Dawson TM (2011) PARIS (ZNF746) repression of PGC-1alpha contributes to neurodegeneration in Parkinson's disease. Cell 144:689 702. CrossRef Medline

Shockett P, Difilippantonio M, Hellman N, Schatz DG (1995) A modified tetracycline-regulated system provides autoregulatory, inducible gene ex- 
pression in cultured cells and transgenic mice. Proc Natl Acad Sci U S A 92:6522-6526. CrossRef Medline

Shults CW (2006) Lewy bodies. Proc Natl Acad Sci U S A 103:1661-1668. CrossRef Medline

Shults CW, Haas RH, Passov D, Beal MF (1997) Coenzyme Q10 levels correlate with the activities of complexes I and II/III in mitochondria from parkinsonian and nonparkinsonian subjects. Ann Neurol 42:261-264. CrossRef Medline

Singleton AB, Farrer M, Johnson J, Singleton A, Hague S, Kachergus J, Hulihan M, Peuralinna T, Dutra A, Nussbaum R, Lincoln S, Crawley A, Hanson M, Maraganore D, Adler C, Cookson MR, Muenter M, Baptista M, Miller D, Blancato J, et al. (2003) alpha-Synuclein locus triplication causes Parkinson's disease. Science 302:841. CrossRef Medline

Spillantini MG, Schmidt ML, Lee VM, Trojanowski JQ, Jakes R, Goedert M (1997) Alpha-synuclein in Lewy bodies. Nature 388:839-840. CrossRef Medline

Sterky FH, Lee S, Wibom R, Olson L, Larsson NG (2011) Impaired mitochondrial transport and Parkin-independent degeneration of respiratory chain-deficient dopamine neurons in vivo. Proc Natl Acad Sci U S A 108: 12937-12942. CrossRef Medline

Terman A, Gustafsson B, Brunk UT (2006) The lysosomal-mitochondrial axis theory of postmitotic aging and cell death. Chem Biol Interact 163: 29-37. CrossRef Medline

Trimmer PA, Borland MK, Keeney PM, Bennett JP Jr, Parker WD Jr (2004)
Parkinson's disease transgenic mitochondrial cybrids generate Lewy inclusion bodies. J Neurochem 88:800-812. CrossRef Medline

Twig G, Elorza A, Molina AJ, Mohamed H, Wikstrom JD, Walzer G, Stiles L, Haigh SE, Katz S, Las G, Alroy J, Wu M, Py BF, Yuan J, Deeney JT, Corkey BE, Shirihai OS (2008) Fission and selective fusion govern mitochondrial segregation and elimination by autophagy. EMBO J 27:433-446. CrossRef Medline

Van Laar VS, Arnold B, Cassady SJ, Chu CT, Burton EA, Berman SB (2011) Bioenergetics of neurons inhibit the translocation response of Parkin following rapid mitochondrial depolarization. Hum Mol Genet 20:927-940. CrossRef Medline

Vanrell L, Di Scala M, Blanco L, Otano I, Gil-Farina I, Baldim V, Paneda A, Berraondo P, Beattie SG, Chtarto A, Tenenbaum L, Prieto J, GonzalezAseguinolaza G (2011) Development of a liver-specific Tet-on inducible system for AAV vectors and its application in the treatment of liver cancer. Mol Ther 19:1245-1253. CrossRef Medline

Vives-Bauza C, Przedborski S (2011) Mitophagy: the latest problem for Parkinson's disease. Trends Mol Med 17:158-165. CrossRef Medline

Xiong H, Wang D, Chen L, Choo YS, Ma H, Tang C, Xia K, Jiang W, Ronai Z, Zhuang X, Zhang Z (2009) Parkin, PINK1, and DJ-1 form a ubiquitin E3 ligase complex promoting unfolded protein degradation. J Clin Invest 119:650-660. CrossRef Medline

Youle RJ, Narendra DP (2011) Mechanisms of mitophagy. Nat Rev Mol Cell Biol 12:9-14. CrossRef Medline 